\title{
BBEP
}

\section{Remuneração inicial dos professores das redes municipais do Paraná no contexto municipal}

Juliana Aparecida Alves Subirá

\section{Resumo}

Nas últimas décadas, a questão da remuneração dos professores tem perpassado as políticas educacionais como expressão da valorização docente, constituindo, este artigo, o resultado do cotejamento das políticas educacionais nacionais, inclusive as municipais, pertinentes à remuneração dos professores. O período proposto para a investigação abrange os anos de 1996 a 2010. Por meio dos dados coletados, construiu-se um panorama da configuração da remuneração inicial dos professores do magistério público no Paraná, no contexto socioeconômico dos municípios selecionados, constatando-se discrepâncias na remuneração inicial praticada entre diversos municípios e semelhanças entre os municípios mais ricos, que possuem as maiores remunerações iniciais.

Palavras-chave: políticas públicas em educação; remuneração dos professores; municípios. 


\section{Abstract \\ Initial remuneration of teachers of the public teaching system in Paraná, in the socioeconomic context of municipalities}

During the last decades, the issue of teachers' remuneration has permeated the educational policies as an expression of the appreciation of teachers. The present article is the result of a parallel between national educational policies and municipal educational policies, related to the remuneration of teachers. The period of this investigation is from 1996 to 2010. It was possible to build up a panorama of initial remuneration of teachers of the public teaching system in Paraná, using the data collected in the socioeconomic context of the selected municipalities. We have noticed discrepancies in the initial remuneration practiced among the different municipalities and also, similarities in the richest municipalities, which have the highest initial salaries.

Keywords: educational policies public; remuneration of teachers; municipalities.

\section{Introdução}

A tipificação da remuneração docente no sistema educacional brasileiro e seu financiamento são diversificados, tanto em relação ao ente federado responsabilizado por ofertar o ensino como pela instância financiadora, privada ou pública.

A conceituação de alguns termos pertinentes à remuneração também se faz necessária. Com base de cálculo distinto e responsabilidades diferentes, têm-se: a) salário, segundo a Consolidação das Leis de Trabalho (CLT), é a retribuição paga diretamente ao empregado pelo tempo de trabalho realizado (Brasil. Decreto-Lei $\left.\left.n^{0} 5.452,1943\right) ; b\right)$ vencimento, definido pela Lei n 8.112/1990, art. 40, é a "retribuição pecuniária pelo exercício de cargo público, com valor fixado em lei"; e c) remuneração, o "montante de dinheiro e/ou bens pagos pelo serviço prestado, incluindo valores pagos por terceiros", sendo o salário uma parte constitutiva da remuneração (Camargo, 2009, p. 342).

No magistério público, os profissionais da educação recebem o vencimento mais as vantagens pecuniárias, o que é denominado por remuneração. A terminologia piso é entendida pelo valor mínimo a ser pago como remuneração inicial aos professores. Trabalharemos com a remuneração inicial dos professores da rede pública municipal, sem as vantagens pecuniárias. 


\section{Um breve percurso pelas políticas educacionais e remuneração}

Com a Constituição de 1988, consolida-se, na letra da lei, a valorização dos profissionais da educação como um dos princípios sob os quais o ensino deveria ser ministrado, com "piso salarial profissional nacional para os profissionais da educação escolar pública, nos termos de lei federal" (Brasil, 1988, grifo nosso).

A proposição da remuneração dos professores na forma de piso salarial profissional aparece pela segunda vez em lei, em toda a história da remuneração docente brasileira. A primeira vez em que ocorreu foi com o Decreto-Lei Imperial.

O Decreto-Lei Imperial estabelecia, no ano de 1827, a faixa salarial para a remuneração docente de $200 \$ 000$ a 500\$000 anuais, ${ }^{1}$ que, em termos de valores reais, no mês de julho de 2010, representaria a faixa salarial de $\mathrm{R} \$ 18.592,35$ a $\mathrm{R} \$ 46.480,87$ ao ano, ou $\mathrm{R} \$ 1.407,10$ a R\$ 3.575,45 ao mês.

No período após a Constituição Federal de 1988, três mecanismos legais vinculados à remuneração dos professores se destacaram no cenário das políticas educacionais: a Emenda Constitucional nº 14/1996, a Emenda Constitucional n 53/2006 e a Lei n 11.738/2008. Desses, o único dispositivo legal que fez menção explícita à remuneração docente foi a Lei $n^{\circ} 11.738 / 2008$, a qual instituiu o piso salarial docente, 181 anos depois da primeira vinculação em lei de valor à remuneração de professores.

As Emendas Constitucionais n 14/1996 e nº 53/2006 regulamentaram o Fundo de Manutenção e Desenvolvimento do Ensino Fundamental e de Valorização do Magistério (Fundef) e o Fundo de Manutenção e Desenvolvimento da Educação Básica e Valorização do Magistério (Fundeb),

1 Disponível em http://www arteducacao.pro.br/homenagem/ queridomestre.htm e acessado em 24/04/2011, o professor Vicente Martins, da Universidade Estadual Vale do Acarau (Sobral/ $\mathrm{CE})$, afirma que "O economista Antônio Luiz Monteiro Coelho da Costa, especialista em cotação de moedas, atendendo minha solicitação, por e-mail, fez a conversão dos réis, de 1827, em reais de 2001 (discutíveis): estima Luiz Monteiro que 200\$000 equivalem a aproximadamente R\$ 8.800,00 (isto é, a um salário mensal de $\mathrm{R} \$ 680$, considerando o $13^{\circ}$ ) e $500 \$ 000$ a aproximadamente $\mathrm{R} \$ 22.000$ ( $\mathrm{R} \$ 1.700$ por mês)". O professor Rubens Barbosa de Camargo, da Feusp, e a professora Marcia Aparecida Jacomini, da Unifesp - Diadema, realizaram a conversão desses valores em reais para o mês de julho de 2010, corrigidos pelo INPC do IBGE (mesmo indicador econômico do Fundeb), explicitado no corpo do texto. respectivamente; o Fundeb substitui o Fundef. A política de fundos atua como mecanismo de redistribuição dos recursos já existentes e vinculados à educação e estabelece a subvinculação mínima de 60\% sobre o percentual de 25\% da receita dos Estados, Distrito Federal e Municípios e dos impostos vinculados à educação para a remuneração condigna do magistério. Segundo a Emenda Constitucional n 14, art. 60, do Ato das Disposições Constitucionais Transitórias (ADCT), na Constituição Federal de 1988:

Nos dez primeiros anos da promulgação desta Emenda, os Estados, o Distrito Federal e os Municípios destinarão não menos de sessenta por cento dos recursos a que se refere o caput do art. 212 da Constituição Federal à manutenção e ao desenvolvimento do ensino fundamental, com o objetivo de assegurar a universalização de seu atendimento e a remuneração condigna do magistério. (Redação dada pela Emenda Constitucional $n^{\circ} 14$, de 1996)

[...]

$\S 5^{\circ}$ Uma proporção não inferior a sessenta por cento dos recursos de cada Fundo referido no $\S 1^{\circ}$ será destinada ao pagamento dos professores do ensino fundamental em efetivo exercício no magistério. (Incluído pela Emenda Constitucional n 14, de 1996)". (grifo nosso). 
O Fundef e o Fundeb estabeleciam somente o percentual mínimo que deveria ser destinado à valorização do magistério e à remuneração dos professores, não especificavam o vencimento inicial mínimo ou piso. Já a Lei do Piso Salarial Profissional Nacional (PSPN), instituída em 2008, estabelece o piso da remuneração do magistério público.

O valor de remuneração especificado em lei não deixa de ser um mecanismo para os entes federados se posicionarem quanto aos planos de carreira, pois o piso estabelece um mínimo que todos devem corresponder, entendido por quantia abaixo da qual os sistemas de ensino não poderão fixar a remuneração do professor da educação básica, no início da carreira, na rede pública (Brasil. Constituição, 1988). É a visibilidade legal que responde à luta em torno de melhores condições de trabalho e de remuneração dos professores. Porém, deve-se analisar se isso não reverterá no achatamento do teto por parte dos entes federados que já praticavam o valor do piso antes mesmo de sua vigência, tendo em vista que a lei estabelece que as carreiras devem ser respeitadas.

Aprovada em 16 de julho de 2008, a Lei n 11.738 do PSPN estipulou que o prazo máximo de adequação dos entes federados era 31 de dezembro de 2009, para o valor determinado como piso salarial dos profissionais do magistério público na educação básica pertinente a plano de carreira e remuneração do piso. Os arts. $2^{\circ}$ e $6^{\circ}$ estabelecem o valor de $\mathrm{R} \$ 950$ para a jornada de trabalho de 40 horas semanais, com formação em nível médio, na modalidade normal, em conformidade com a Lei de Diretrizes e Bases da Educação Nacional (LDB). Segundo a jornada de trabalho, essa lei define o limite máximo de dois terços da carga horária em atividade direta com os educandos.

O valor desse piso deveria ser atualizado anualmente, no mês de janeiro, a partir de 2009, tendo por base de cálculo o mesmo percentual de crescimento do valor anual mínimo por aluno, referente aos anos iniciais do ensino fundamental urbano (Brasil. Lei $\left.n^{\circ} 11.738,2008\right)$. Esse mecanismo de reajuste do PSPN remete-se ao Fundeb.

Nos anos de 2008 e 2009, o valor do PSPN correspondia a R\$ 950, em valores nominais, e, em 2010, a R\$1.024,67. Esses valores do piso salarial docente, atualizados pelo Índice Nacional de Preços ao Consumidor (INPC), correspondem à remuneração de $\mathrm{R} \$ 1.056,08$, em 2008, $\mathrm{R} \$ 1.013,85$, em 2009, e R\$ 1024,67, em 2010.

O valor da remuneração dos professores com jornada diferenciada de 40 horas semanais deve ser calculado com a aplicação do mínimo da proporcionalidade da jornada de trabalho, tendo como referência a jornada de 40 horas semanais e a remuneração correspondente a R\$ 950 (Brasil. Lei $\left.n^{\circ} 11.738,2008\right)$.

Os entes federados deveriam se adequar às legislações de âmbito nacional. Por meio da análise dos planos de carreira e das tabelas salariais, temos a configuração da remuneração inicial dos professores das redes municipais no Estado do Paraná. 


\section{Remuneração inicial dos professores das redes municipais do Estado do Paraná no contexto socioeconômico}

Em uma mancha de ocupação contínua, os municípios escolhidos para a investigação formam, com Curitiba, o aglomerado metropolitano. Curitiba é denominada de polo metropolitano, com concentração de 57,3\% da população da Região Metropolitana de Curitiba (RMC), e o Primeiro Anel da Região Metropolitana de Curitiba (PARMC) é formado pelos municípios limítrofes com o polo, com concentração de 35,1\% da população da RMC (IBGE, 2010). Os municípios que fazem parte do PARMC são: Almirante Tamandaré, Araucária, Campina Grande do Sul, Campo Largo, Campo Magro, Colombo, Fazenda Rio Grande, Pinhais, Piraquara, Quatro Barras e São José dos Pinhais (Ipardes, 2004). Ao trabalhar com o PARMC nas análises, incluímos o município de Curitiba, sendo assim, ao ler PARMC, deve-se compreender Curitiba e os 11 municípios limítrofes com a capital.

Para acesso aos dados ${ }^{2}$ de cada município do PARMC, recorreu-se às prefeituras municipais, aos sítios eletrônicos e aos sindicatos municipais. A qualidade das informações disponíveis na rede mundial de computadores apresenta variação entre os municípios, o que ocasionou alguma dificuldade para o levantamento dos dados.

Na remuneração dos professores do magistério público, têm-se três níveis de habilitação. Para análise, trabalharemos com a remuneração inicial do professor com habilitação em nível de graduação com jornada de trabalho de 20 horas semanais, entendendo que, dos 12 municípios do PARMC, somente três ainda permitem o ingresso do professor com habilitação em nível médio, os outros nove exigem a habilitação em nível superior com licenciatura plena na área da educação.

Para a análise da remuneração inicial dos professores, no contexto socioeconômico municipal, foram consideradas informações pertinentes à economia, educação e população dos municípios do PARMC. Para tanto, os dados selecionados para análise foram: receita do município; gasto com Manutenção e Desenvolvimento do Ensino (MDE); ganho/perda com o Fundef/Fundeb; matrículas do ensino fundamental; e remuneração inicial dos professores da rede pública municipal. Todos os dados trabalhados neste artigo foram atualizados pelo INPC de dezembro de 2010 para comparação de grandezas.

A proposta inicial do período de análise dos dados era dos anos de 1996 a 2010. Ante as informações disponibilizadas pelos municípios, a análise foi feita com os anos de referência que possuem a maior quantidade de informações acerca da remuneração inicial dos professores, nos períodos do Fundef, Fundeb e PSPN.

No período do Fundef, o ano de 2003 é o que corresponderia ao requisito supracitado, porém, dois municípios do PARMC não possuíam essas informações - Colombo e Piraquara. Como em 2004 o município de Piraquara possuía o valor da remuneração, esse ano foi considerado para

${ }^{2}$ A coleta desses dados começou a análise. O município de Colombo permanecerá com a ausência dessa em março de 2011, no PARMC. informação, pois as tabelas salariais disponibilizadas iniciam em 2006. 
Situação semelhante ocorreu com a análise da remuneração inicial no período do Fundeb ao ser selecionado o ano de 2007, pois os municípios de Campina Grande do Sul e de São José dos Pinhais não possuíam informação de remuneração inicial, mas, no ano de 2008, Campina Grande possuía. Já em São José dos Pinhais, depois de 2003, a próxima tabela disponibilizada foi a de 2010.

No período do PSPN, o ano selecionado foi 2010, por compreender também o ano final desta análise.

Considerando as situações no período dos fundos, os recortes de tempo selecionados para análise da remuneração inicial dos professores foram 2003/2004, 2007/2008 e 2010. Esses também foram os anos em que as outras informações concernentes à análise de contexto foram examinadas.

Os dados acerca da receita dos municípios, do gasto em MDE e da perda/ganho com o Fundef/Fundeb foram coletados no sítio eletrônico ${ }^{3}$ do Fundo Nacional de Desenvolvimento da Educação (FNDE), no Relatório Resumido da Execução Orçamentária (RREO), Anexo X da Lei de Responsabilidade Fiscal dos Relatórios Municipais, no Sistema de Informações sobre Orçamentos Públicos em Educação (Siope - FNDE, 2003, 2007, 2010). As informações de matrículas dos municípios foram coletadas no sítio eletrônico do Inep/MEC, em Censo Escolar.

\section{Perfil dos municípios do PARMC}

A Tabela comparativa 1 apresenta uma breve caracterização dos municípios do PARMC quanto a sua demografia, extensão geográfica, economia, indicadores sociais e ano de fundação.

Dos 12 municípios do PARMC, somente quatro foram fundados após a Constituição Federal de 1988, o que equivale a um terço do PARMC: Campo Magro, Fazenda Rio Grande, Pinhais e Piraquara, fundados em anos que precedem a implantação do Fundef.

O município é considerado ente federado desde a Constituição Federal de 1988, o que lhe outorga, dentre suas responsabilizações, a autonomia de legislar.

Então, cabe destacar a questão da municipalização do ensino mediante mecanismos legais. A Constituição Federal de 1988 explicitou que o dever do Estado com a educação seria a garantia de educação básica obrigatória e gratuita, em regime de colaboração, e responsabilizou os municípios para atuarem prioritariamente no ensino fundamental e na educação infantil. O Fundef estabeleceu que o repasse do fundo aos municípios fosse feito segundo o censo das matrículas no município, tendo, entre seus princípios, a universalização do ensino (Brasil. Lei no 9.424, 1996). Esses dois mecanismos legais reforçam a ideia da municipalização do ensino.

O Fundef tinha o pressuposto da universalização do ensino segundo a motivação do recebimento de recursos financeiros proporcional ao número
${ }^{3}$ http://www.tce.pr.gov.br/ e http://www.fnde.gov.br/index. $\mathrm{php} /$ sistemas-siope 
de alunos atendidos, porém, Arelaro (2007) evidencia que, ao observar os dados estatísticos, o que se constata é a municipalização no atendimento ao ensino fundamental em foco e nem tanto a sua universalização.

Tabela 1 - Perfil dos Municípios do PARMC

\begin{tabular}{|c|c|c|c|c|c|c|}
\hline Município & $\begin{array}{c}\text { População } \\
\text { (pessoas) } \\
2010\end{array}$ & $\begin{array}{c}\text { Área da } \\
\text { unidade } \\
\text { territorial } \\
\left(\mathrm{Km}^{2}\right) 2010\end{array}$ & $\begin{array}{c}\text { PIB/per } \\
\text { capita } \\
(\mathrm{R} \$ 1,00) \\
2009\end{array}$ & $\begin{array}{c}\text { Taxa } \\
\text { Pobreza } \\
\text { (\%) } 2000\end{array}$ & $\begin{array}{c}\text { Taxa } \\
\text { Analfabe- } \\
\text { tismo (\%) } \\
2000\end{array}$ & $\begin{array}{c}\text { Ano } \\
\text { Fundação }\end{array}$ \\
\hline Araucária & 199.123 & 471,337 & 101.411 & 17,71 & 5,80 & 1890 \\
\hline São José dos Pinhais & 264.210 & 944,280 & 41.217 & 14,03 & 5,70 & 1897 \\
\hline Quatro Barras & 19.851 & 181,265 & 27.510 & 17,46 & 7,20 & 1961 \\
\hline Curitiba & 1.751 .907 & 435,495 & 24.720 & 8,61 & 5,40 & 1854 \\
\hline Pinhais & 117.008 & 61,137 & 20.129 & 14,18 & 5,80 & 1992 \\
\hline $\begin{array}{l}\text { Campina Grande } \\
\text { do Sul }\end{array}$ & 38.769 & 540,631 & 12.876 & 21,35 & 7,80 & 1956 \\
\hline Campo Largo & 112.377 & $1.282,56$ & 11.922 & 15,91 & 6,80 & 1873 \\
\hline Colombo & 212.967 & 197,805 & 7.547 & 17,34 & 7,20 & 1943 \\
\hline Campo Magro & 24.843 & 278,224 & 7.483 & 21,46 & 9,70 & 1995 \\
\hline Fazenda Rio Grande & 81.675 & 115,377 & 5.968 & 20,11 & 7,20 & 1990 \\
\hline $\begin{array}{l}\text { Almirante } \\
\text { Tamandaré }\end{array}$ & 103.204 & 191,114 & 5.926 & 22,17 & 10,10 & 1956 \\
\hline Piraquara & 93.207 & 225,223 & 5.489 & 23,17 & 8,60 & 1992 \\
\hline Média & & & & 17,79 & 7,28 & \\
\hline
\end{tabular}

Fonte: IBGE (2000, 2010), Ipardes (2010). Elaborado pela autora.

No Estado do Paraná, a municipalização do ensino é parte resultante de uma antiga história de iniciativas voltadas para a sua concretização por meio de várias modalidades de parcerias entre o governo estadual e as prefeituras, na tentativa do desenho de um sistema de colaboração e responsabilidades compartilhadas, as quais vieram a ser empregadas a partir de 1991 (Santos, 2001).

Os estudos de documentos da Secretaria de Estado e Educação do Paraná (Seed) e do contexto político administrativo e financeiro realizados por Santos (2001) permitem compreender que o processo de municipalização do ensino encontra, na década de 1950, medidas administrativas como mecanismos preparatórios de descentralização da administração da rede estadual. Em 1964, o Paraná implantou seu sistema de ensino - Lei do Sistema de Ensino -, o que repercutiu na expansão da oferta municipal da educação primária. A reforma do ensino brasileiro, através da Lei n 5.692/1971, efetivou o aspecto político na ampliação da dimensão administrativa pelos municípios, no atendimento ao ensino de 
$1^{\circ}$ grau. O Estado do Paraná reforça esse mecanismo, por meio do Plano de Reforma do Ensino (1973-1976), ao estabelecer o prazo de cinco anos de etapas a serem cumpridas no atendimento à educação de $1^{\circ}$ grau pelos municípios e com recursos que auxiliariam no financiamento dessa ampliação, mediante projetos de cooperação até em âmbito federal, como o Promunicípio.

Portanto, no período que vai dos anos de 1960 a 1980, a natureza administrativo-financeira do processo de municipalização do ensino evidenciou mecanismos favoráveis a essa implantação como parte de "um movimento mais amplo de âmbito nacional" (Santos, p. 12, 2001), decorrentes da reforma de ensino e participação do Estado em projetos federais.

Nos anos posteriores ao fim da ditadura militar e ao processo de abertura política, tem-se a promulgação da Constituição Federal de 1988. Diante desse contexto, na década de 1980, o Estado do Paraná vivenciou a precarização das condições de financiamento público decorrente da crise econômica herdada após a ditadura militar, refletida sobre as condições de financiamento do ensino no Estado e nos municípios. Em 1988 e 1990, foram registradas duas grandes greves por parte dos professores do sistema de ensino de $1^{\circ}$ grau, dado o arrocho salarial e a crescente precarização das situações de trabalho no ensino municipal, ante o aumento de matrículas da rede municipal (Santos, 2001).

Em 1991, o governo estadual firmou o Termo de Cooperação Técnica Financeira entre a Seed e os municípios, com a disposição de ceder servidores estaduais e/ou verbas para a rede municipal de ensino na transferência de recursos à sua manutenção. Em 1992, 81,6\% dos municípios aderiram ao termo, muito provavelmente com vista aos estímulos financeiros para os municípios parceiros (Santos, 2001). Esse termo apresentava alguns problemas destacados no Fórum Paraense na Defesa da Escola Pública, Gratuita e Universal (1991) concernentes à valorização do professor, enquanto carreira, salário, regime de trabalho e organização dos profissionais da educação:

não há garantia de tratamento isonômico para a carreira e salários unificados nacionalmente (p. 3); não há falta de definição de qual instância arcará com o ônus da manutenção de pessoal administrativo e de serviços das escolas onde o Estado e o Município mantenham classes (p. 4); risco de tratamento desigual na formulação e implantação de critérios, padrão de exigência e de qualidade para o provimento dos cargos (p. 4); indefinição sobre o regime de trabalho (p. 3); risco de perda de direitos já alcançados pela categoria (p. 3); risco de esfacelamento da organização sindical (p. 3).

Essas ponderações realizadas no fórum foram desconsideradas pelo Grupo de Planejamento Setorial da Secretaria de Estado da Educação ao designar, em 1992, o Termo Cooperativo da Parceria Educacional (TCPE), em que as reformulações orientavam a municipalização até 1994. Conforme Santos (2001), não houve alterações substantivas até a 
implantação do Fundef, mas seriam necessários outros estudos para essa análise. A política do Fundef foi o solo fértil no processo de financiamento da municipalização do ensino, mediante o recebimento do fundo por matrículas no ensino fundamental.

Essa digressão detalhando o processo de municipalização no Estado foi necessária para poder contextualizar a condição de expansão das redes municipais do Paraná e, consequentemente, do PARMC.

Entre os municípios mais antigos estão os com os maiores PIB/per capita e maior concentração da população do PARMC. São eles: Araucária, Curitiba e São José dos Pinhais. Os municípios de Araucária e São José dos Pinhais estão entre os mais industrializados do PARMC, como podemos verificar na Tabela 2.

Tabela 2 - Distribuição do Produto Interno Bruto (PIB) nos Municípios do PARMC

\begin{tabular}{|c|c|c|c|c|c|c|}
\hline \multicolumn{7}{|c|}{ PIB } \\
\hline \multirow{2}{*}{ Municípios } & Agropecuária & Indústria & Serviços & Agropecuária & Indústria & Serviços \\
\hline & \multicolumn{3}{|c|}{ Números absolutos } & \multicolumn{3}{|c|}{$\%$} \\
\hline Almirante Tamandaré & 8.795 & 155.746 & 368.235 & 2 & 29 & 69 \\
\hline Araucária & 51.066 & 4.656 .428 & 5.923 .105 & 0 & 44 & 56 \\
\hline Campina Grande do Sul & 9.952 & 95.285 & 320.412 & 2 & 23 & 75 \\
\hline Campo Largo & 45.633 & 362.176 & 787.079 & 4 & 30 & 66 \\
\hline Campo Magro & 20.686 & 38.592 & 104.700 & 13 & 23 & 64 \\
\hline Colombo & 21.979 & 417.929 & 1.231 .939 & 1 & 25 & 74 \\
\hline Curitiba & 16.193 & 7.366 .563 & 30.508 .607 & 0 & 19 & 81 \\
\hline Fazenda Rio Grande & 4.676 & 109.533 & 327.497 & 1 & 25 & 74 \\
\hline Pinhais & 1.248 & 652.858 & 1.419 .889 & 0 & 32 & 68 \\
\hline Piraquara & 6.744 & 132.905 & 304.617 & 1 & 30 & 69 \\
\hline Quatro Barras & 1.294 & 267.424 & 175.432 & 0 & 60 & 40 \\
\hline São José dos Pinhais & 48.245 & 5.231 .008 & 4.662 .329 & 0 & 53 & 47 \\
\hline
\end{tabular}

Fonte: IBGE (2009). Elaborado pela autora.

Na macroeconomia dos municípios do PARMC, a maioria tem o PIB predominantemente resultante de serviços, com destaque aos municípios de Colombo, Pinhais e Curitiba, que apresentam os maiores percentuais do PIB em serviços e, conforme a Tabela 1, estão entre os de maior densidade demográfica. De acordo com os indicadores sociais das taxas de pobreza e de analfabetismo, Curitiba, a capital do Estado, é o município no PARMC com menor taxa de pobreza e de analfabetismo, 8,61\% e 5,40\%, respectivamente, e ainda o maior percentual do PIB em serviços, $81 \%$. 
Os municípios de Araucária, Quatro Barras e São José dos Pinhais são os mais industrializados, conforme o percentual do PIB resultante das indústrias.

Araucária é o município com maior PIB/per capita e seu percentual está dividido entre serviços, 56\%, e indústrias, 44\%. Seu fortalecimento econômico se deve ao parque industrial, que conta com 585 empresas, entre elas, alguns gigantes do setor petroquímico, metalúrgico e mecânico e também de outros pequenos segmentos. A transformação da economia desse município teve início no ano de 1972, com a instalação milionária da Refinaria Presidente Getúlio Vargas (Repar), que estimulou a criação dos parques industriais e abrigou uma das refinarias da Petrobrás. Os indicadores sociais expressam que a taxa de pobreza chega a ser o dobro do município de Curitiba, o que reflete parte da desigualdade na redistribuição de renda. Quanto ao analfabetismo, Araucária é o terceiro município com a menor taxa no PARMC.

Em Quatro Barras e São José dos Pinhais, o percentual do PIB resultante de indústrias chega a ser maior do que o de serviços. Nos últimos quatro anos, o município de Quatro Barras contou com a instalação de mais de dez novas empresas, o que contribuiu para o aumento na arrecadação municipal de 82\%: é o terceiro com o maior PIB/per capita, elevando-o ao patamar dos municípios mais ricos no PARMC. Porém, sua taxa de pobreza é bem próxima à de Araucária, o que caracteriza também a desigualdade na distribuição da renda; além disso, sua taxa de analfabetismo é a maior entre os municípios mais ricos. São José dos Pinhais se destaca por ser o terceiro polo automotivo do País, abrigando montadoras da Volkswagen, Audi, Nissan e Renault, assim como grandes fábricas de autopeças. Para além de ser o município sede do aeroporto do Estado do Paraná, é o segundo município no PARMC com maior densidade demográfica e menor taxa de pobreza e de analfabetismo, o que é reflexo da ação das políticas sociais municipais.

Entre os municípios do PARMC, Campo Magro se destaca por ser o único com percentual significativo do PIB resultante da agropecuária, $13 \%$, pois a base de sua economia é a agricultura familiar orgânica, o artesanato e o turismo rural. No entanto, muitos de seus habitantes optam por trabalhar em outros municípios, dada a escassez de empregos - isso expressa o fato de estar entre os de maiores taxas de pobreza e analfabetismo.

Almirante Tamandaré se destaca por ser o município no PARMC com maior taxa de pobreza, 22,17\%, e de analfabetismo, 10,10\%. Sua principal atividade econômica é a indústria de cal, seguida do turismo como importante atividade econômica. Cerca de 53\% da população desse município trabalha em Curitiba, o que lhe reserva o título de cidade dormitório, e a economia é muito incipiente, o que lhe confere as piores taxas de pobreza e analfabetismo. 


\section{Contexto socioeconômico do PARMC}

Para a análise do movimento das receitas nos municípios foi realizado o dimensionamento da receita per capita, aplicando-se a razão entre a receita municipal e a população. Para o dimensionamento da população, a coleta das informações foi realizada na base de dados do Instituto Brasileiro de Geografia e Estatística (IBGE), por meio dos censos populacionais dos anos de 2000 e 2010.

Tabela 3 - Demografia do PARMC e Taxa de Crescimento Acumulado

\begin{tabular}{|l|r|r|r|}
\hline \multicolumn{1}{|c|}{ Municípios } & $\mathbf{2 0 0 0}(\mathbf{h a b})$ & $\mathbf{2 0 1 0}(\mathbf{h a b})$ & $\begin{array}{c}\text { Taxa de Crescimento } \\
\text { Acumulado (\%) }\end{array}$ \\
\hline Almirante Tamandaré & 88.277 & 103.204 & 17 \\
\hline Araucária & 94.258 & 119.123 & 26 \\
\hline Campina Grande do Sul & 34.566 & 38.769 & 12 \\
\hline Campo Largo & 92.782 & 112.377 & 21 \\
\hline Campo Magro & 20.409 & 24.843 & 22 \\
\hline Colombo & 183.329 & 212.967 & 16 \\
\hline Curitiba & 1.587 .315 & 1.751 .907 & 10 \\
\hline Fazenda Rio Grande & 62.877 & 81.675 & 30 \\
\hline Pinhais & 102.985 & 117.008 & 14 \\
\hline Piraquara & 72.886 & 93.207 & 28 \\
\hline Quatro Barras & 16.161 & 19.851 & 29 \\
\hline São José dos Pinhais & 204.316 & 264.210 & \\
\hline
\end{tabular}

Fonte: IBGE (2000, 2010). Elaborado pela autora.

Com base nas informações do censo populacional do PARMC, Fazenda Rio Grande, Piraquara e São José dos Pinhais foram os municípios com maior crescimento. Observa-se que as razões são distintas entre os dois primeiros e São José dos Pinhais, pois Fazenda Rio Grande e Piraquara cresceram com o PIB em serviços, conforme percentual da Tabela 2, tendo como principal característica o fato de serem municípios dormitórios. Já São José dos Pinhais cresce por sua expansão industrial, segundo o percentual do PIB em indústria.

Em Curitiba, apurou-se a menor taxa percentual de crescimento

${ }^{4}$ Para aprofundar sobre a temática da mobilidade geográfica na RMC indicamos a leitura do trabalho de Nojima, Moura e Silva, publicado pelo Ipardes em 2004 e o de Noguchi (2009).

${ }^{5}$ http://www.comec.pr.gov.br/ modules/conteudo/conteudo. php? conteudo $=89$. acumulado na população. Estudos ${ }^{4}$ indicam que entre os municípios da RMC ocorre a migração populacional, e isso se deve à facilidade na mobilidade urbana em questões geográficas e econômicas em torno do PARMAC. ${ }^{5}$ Em termos geográficos, os municípios do PARMC estão próximos, sendo que os mais distantes são Quatro Barras, a $30 \mathrm{~km}$ da capital, e Campina Grande do Sul, a 28 km (Nojima; Moura; Silva, 2004). 


\section{Receita municipal}

A partir dos dados demográficos de 2000 e 2010, foi realizado o cálculo da renda per capita, considerando para o ano de 2003 o censo populacional de 2000 e, para os anos de 2007 e 2010, o censo populacional de 2010.

\section{Tabela 4 - Renda Per Capita Municipal, em Valores Reais Atualizados pelo} Índice Nacional de Preços ao Consumidor (INPC - Dez. 2010)

\begin{tabular}{|l|r|r|r|r|}
\hline \multicolumn{1}{|c|}{ Município } & 2003 & 2007 & 2010 & $\begin{array}{c}\text { Taxa Crescimento } \\
\text { Acumulado }\end{array}$ \\
\hline Almirante Tamandaré & 312 & 516 & 534 & $71 \%$ \\
\hline Araucária & 2886 & 3553 & 3675 & $27 \%$ \\
\hline Campina Grande do Sul & 683 & 935 & 1036 & $52 \%$ \\
\hline Campo Largo & 584 & 875 & 865 & $48 \%$ \\
\hline Campo Magro & 791 & 1035 & 1115 & $41 \%$ \\
\hline Colombo & 387 & 533 & 653 & $69 \%$ \\
\hline Curitiba & 878 & 1158 & 1218 & $39 \%$ \\
\hline Fazenda Rio Grande & 373 & 612 & 590 & $58 \%$ \\
\hline Pinhais & 756 & 1032 & 1309 & $74 \%$ \\
\hline Piraquara & 492 & 885 & 856 & $32 \%$ \\
\hline Quatro Barras & 1167 & 1666 & 1544 & $130 \%$ \\
\hline São José dos Pinhais & 831 & 1434 & 1908 & \\
\hline
\end{tabular}

Fonte: FNDE (2003, 2007, 2010); Inep/MEC (2003, 2007, 2010). Elaborado pela autora.

O município que teve maior incremento na renda per capita foi São José dos Pinhais - esse fato pode ser resultante da sua expansão industrial.

A maioria dos municípios apresenta movimento inconstante na receita per capita municipal nos três anos de análise, o que reflete na ordem diversificada hierarquicamente. Três municípios mantiveram suas posições constantes: Almirante Tamandaré, que nos três anos foi o mais pobre; Araucária, o mais rico; e Campina Grande, o intermediário, com valores próximos à mediana nos três anos. A mediana da receita per capita municipal no ano de 2003, em valores reais, foi de R\$ 720; em 2007, de $\mathrm{R} \$$ 984; e, em 2010, de R\$1.075.

Com base na Tabela 4, foi localizado o movimento dos municípios mais ricos, dos intermediários e dos mais pobres do PARMC, durante os anos selecionados, o que permite a hierarquização apresentada no Quadro 1.

Essa hierarquização subsidiou a divisão do PARMC em três grupos, conforme a receita per capita disponibilizada no ano de 2010: os municípios mais ricos, os municípios intermediários e os municípios mais pobres. A escolha de 2010 se deve ao fato de ser o ano eleito para atualização dos valores nominais e também o ano final desta pesquisa. O valor de corte intermediário para classificação dos grupos foi a mediana 
da receita per capita do ano de 2010, expressado no valor de $\mathrm{R} \$ 1.075$. Portanto, os municípios intermediários são os que se aproximaram do valor da mediana.

\section{Quadro 1 - Hierarquia do PARMC, segundo a Receita Per Capita 2003, 2007 e 2010}

\begin{tabular}{|l|}
\multicolumn{1}{|c|}{2003} \\
\hline Araucária \\
\hline Quatro Barras \\
\hline Curitiba \\
\hline São José dos Pinhais \\
\hline Campo Magro \\
\hline Pinhais \\
\hline Campina Grande do \\
Sul \\
\hline Campo Largo \\
\hline Piraquara \\
\hline Colombo \\
\hline Fazenda Rio Grande \\
\hline Almirante Tamandaré \\
\hline
\end{tabular}

\begin{tabular}{|l|}
\multicolumn{1}{|c|}{2007} \\
\hline Araucária \\
\hline Quatro Barras \\
\hline São José dos Pinhais \\
\hline Curitiba \\
\hline Campo Magro \\
\hline Pinhais \\
\hline Campina Grande do \\
\hline Sul \\
\hline Piraquara \\
\hline Campo Largo \\
\hline Fazenda Rio Grande \\
\hline Colombo \\
\hline Almirante Tamandaré \\
\hline
\end{tabular}

\begin{tabular}{|l|}
\multicolumn{1}{|c|}{2010} \\
\hline Araucária \\
\hline São José dos Pinhais \\
\hline Quatro Barras \\
\hline Pinhais \\
\hline Curitiba \\
\hline Campo Magro \\
\hline Campina Grande do \\
Sul \\
\hline Campo Largo \\
\hline Piraquara \\
\hline Colombo \\
\hline Fazenda Rio Grande \\
\hline Almirante Tamandaré \\
\hline
\end{tabular}

Fonte: FNDE (2003, 2007, 2010) e IBGE (2000, 2010). Elaborado pela autora.

O primeiro grupo, formado pelos municípios mais ricos, apresentou a receita per capita de $\mathrm{R} \$ 1.500$ ou mais. O segundo grupo foi representado pelos municípios de receita per capita na faixa entre $\mathrm{R} \$ 1.000$ e $\mathrm{R} \$ 1.499$, e o terceiro grupo pelos municípios mais pobres, com receita per capita abaixo de $\mathrm{R} \$ 1.000$.

O município de Curitiba, embora apresentasse no ano de 2010 o valor da receita per capita para estar no grupo dos intermediários, foi colocado no grupo dos mais ricos por causa da trajetória que desempenhou nos anos de coleta dos dados. Em 2003, estava em terceiro lugar no ranking dos municípios mais ricos, em 2007, em quarto, e, em 2010, em quinto.

\section{Quadro 2 - Classificação dos Municípios do PARMC, segundo Receita Per Capita - 2010}

\begin{tabular}{|l|}
\hline \multicolumn{1}{|c|}{$\begin{array}{c}\text { Municípios Mais } \\
\text { Ricos }\end{array}$} \\
\hline Araucária \\
\hline Quatro Barras \\
\hline $\begin{array}{l}\text { São José dos } \\
\text { Pinhais }\end{array}$ \\
\hline Curitiba \\
\hline
\end{tabular}

\begin{tabular}{|l|}
\multicolumn{1}{|c|}{\begin{tabular}{c}
\multicolumn{1}{c|}{ Municípios } \\
Intermediários
\end{tabular}} \\
\hline Pinhais \\
\hline Campo Magro \\
\hline $\begin{array}{l}\text { Campina Grande } \\
\text { do Sul }\end{array}$ \\
\hline
\end{tabular}

\begin{tabular}{|l|}
\hline \multicolumn{1}{|c|}{$\begin{array}{c}\text { Municípios Mais } \\
\text { Pobres }\end{array}$} \\
\hline Campo Largo \\
\hline Piraquara \\
\hline Colombo \\
\hline Fazenda Rio Grande \\
\hline $\begin{array}{l}\text { Almirante } \\
\text { Tamandaré }\end{array}$ \\
\hline
\end{tabular}


Araucária foi o município que apresentou maior receita per capita, devido a sua arrecadação de impostos municipais ser a maior. Ter a maior receita per capita não significa dizer que a renda do município seja redistribuída equitativa ou igualitariamente entre a população. No ano de 2010, a receita per capita desse município chegou a ser quase ${ }^{6}$ duas vezes maior que a do segundo município com maior receita per capita, São José dos Pinhais. Essa classificação dos grupos foi utilizada nas análises que se seguem.

\section{Matrículas da rede municipal}

As informações acerca das matrículas foram coletadas no sítio eletrônico do Inep/MEC, por meio do censo escolar dos respectivos anos de análise.

Na Tabela 5, segundo a classificação hierárquica da receita per capita, é possível visualizar o movimento das matrículas nos três grupos dos municípios do PARMC.

Tabela 5 - Matrículas do PARMC - 2003, 2007 e 2010

\begin{tabular}{|c|c|c|c|c|}
\hline \multicolumn{4}{|c|}{ Matrículas no PARMC } & $\begin{array}{l}\text { Taxa de Crescimento } \\
\text { Acumulado Matrícula }\end{array}$ \\
\hline \multicolumn{5}{|l|}{ Municípios mais ricos } \\
\hline & 2003 & 2007 & 2010 & \\
\hline Araucária & 19.877 & 20.648 & 21.648 & $9 \%$ \\
\hline Quatro Barras & 2.176 & 2.110 & 2.172 & $0 \%$ \\
\hline São José dos Pinhais & 25.891 & 27.363 & 28.263 & $9 \%$ \\
\hline Curitiba & 130.343 & 131.505 & 132.730 & $2 \%$ \\
\hline \multicolumn{5}{|l|}{ Municípios intermediários } \\
\hline & 2003 & 2007 & 2010 & \\
\hline Pinhais & 11.037 & 12.633 & 12.958 & $17 \%$ \\
\hline Campo Magro & 2.952 & 3.171 & 2.934 & $-1 \%$ \\
\hline Campina Grande do Sul & 5.930 & 5.095 & 4.613 & $-22 \%$ \\
\hline \multicolumn{5}{|l|}{ Municípios mais pobres } \\
\hline & 2003 & 2007 & 2010 & \\
\hline Campo Largo & 12.480 & 12.783 & 12.299 & $-1 \%$ \\
\hline Piraquara & 9.531 & 10.251 & 10.089 & $6 \%$ \\
\hline Colombo & 26.033 & 25.798 & 25.561 & $-2 \%$ \\
\hline Fazenda Rio Grande & 10.057 & 9.354 & 9.534 & $-5 \%$ \\
\hline Almirante Tamandaré & 12.222 & 11.177 & 10.097 & $-17 \%$ \\
\hline
\end{tabular}

Fonte: Inep/ MEC (2003, 2007, 2010). Elaborado pela autora.

O maior crescimento das matrículas municipais no PARMC foi registrado no município de Pinhais, cuja expansão representou o
${ }^{6}$ Corresponde exatamente ao valor de 1,9261006. 
percentual de $17 \%$, estando entre os municípios com as menores taxa de analfabetismo. Com relação ao crescimento populacional, encontra-se entre os municípios de menor crescimento. Em razão inversa, tem-se Almirante Tamandaré, cujo decréscimo nas matrículas foi de $17 \%$, com o mesmo percentual para crescimento populacional, representando o município com as maiores taxas de analfabetismo e de pobreza no PARMC.

No grupo dos municípios mais ricos do PARMC o movimento foi de expansão das matrículas na rede municipal, com exceção de Quatro Barras, que não cresceu em matrículas, é o menor município em área geográfica, o de maior crescimento populacional, com PIB/per capita maior que a capital, e taxa de pobreza relativamente alta, em comparação aos demais municípios do PARMC. Isso representa a desigualdade na redistribuição da renda no município e a necessidade do estudo de caso quanto ao encolhimento da rede municipal ante o crescimento populacional.

Pinhais e Piraquara, pertencentes ao grupo dos municípios intermediários e mais pobres, respectivamente, são os únicos de seu grupo que expandiram as matrículas na rede municipal; nos outros municípios desse grupo ocorreu o decréscimo das matrículas. Segundo a ampliação da rede municipal, por meio das matrículas, e o crescimento na remuneração dos professores, o município de Pinhais ocuparia o mesmo lugar de Quatro Barras. Pinhais, apesar de estar entre as 100 melhores cidades brasileiras para se fazer negócios, apresentou receita per capita inferior à de Quatro Barras. Piraquara é considerado o município reservatório de água da região metropolitana e, por possuir grandes áreas de proteção ambiental, tem restrições às atividades industriais, o que reflete na limitação do desenvolvimento econômico. Esse município investe no turismo de aventura e agroturismo. Pinhais e Piraquara se configuram no âmbito da economia como municípios que fazem esforços no atendimento à cobertura da educação básica ante as matrículas e remuneração inicial dos professores.

Cabe o destaque para Campina Grande do Sul, o município do grupo dos intermediários que apresentou o maior percentual de decréscimo das matrículas, $22 \%$, está entre os municípios com menor crescimento populacional e é o segundo com maior taxa de pobreza no PARMC.

Dos municípios que apresentaram as maiores taxas de crescimento populacional no PARMC, Fazenda Rio Grande (30\%), São José dos Pinhais (29\%), Piraquara (28\%) e Araucária (26\%), somente Fazenda Rio Grande registrou o encolhimento das matrículas da rede municipal, fato que expressa a deficiência do município em administrar seu crescimento populacional ante a sua condição econômica, refletindo também na extremidade da política social e educativa sobre as matrículas.

\section{Gasto em MDE}

Os dados pertinentes ao gasto em MDE foram obtidos no FNDE, por meio do Relatório Municipal do SIOPE, segundo os anos de corte deste 
estudo. Para análise do movimento dos custos em MDE, foi aplicada a razão entre o gasto em MDE e as matrículas municipais. A Tabela 6 apresenta esses dados conforme a classificação da receita per capita no PARMC, em valores reais, nos respectivos anos de análise.

Tabela 6 - Gastos em Manutenção e Desenvolvimento do Ensino dos Municípios do PARMC, em Valores Reais Corrigidos pelo Índice Nacional de Preços ao Consumidor (INPC - Dez. 2010)

$-2003,2007$ e 2010

\begin{tabular}{|c|c|c|c|c|}
\hline Hierarquia dos $n$ & ípios no PARM & , segundo sua 1 & queza & $\begin{array}{c}\text { Taxa de } \\
\text { Crescimento }\end{array}$ \\
\hline Municípios mais ricos & & & & \\
\hline & 2003 & 2007 & 2010 & \\
\hline Araucária & 65.053 .146 & 83.557 .525 & 82.091 .562 & $26 \%$ \\
\hline Quatro Barras & 4.608 .829 & 7.590 .434 & 8.132 .577 & $76 \%$ \\
\hline São José dos Pinhais & 61.808 .377 & 72.939 .699 & 115.221 .455 & $86 \%$ \\
\hline Curitiba & 483.090 .596 & 500.323 .105 & 655.898 .084 & $36 \%$ \\
\hline Municípios intermediári & & & & \\
\hline & 2003 & 2007 & 2010 & \\
\hline Pinhais & 27.684 .373 & 34.463 .955 & 48.684 .404 & $76 \%$ \\
\hline Campo Magro & 5.695 .721 & 7.735 .023 & 9.054 .470 & $59 \%$ \\
\hline Campina Grande do Sul & 10.477 .001 & 12.119 .398 & 19.748 .020 & $88 \%$ \\
\hline Municípios mais pobres & & & & \\
\hline & 2003 & 2007 & 2010 & \\
\hline Campo Largo & 26.298 .750 & 30.927 .977 & 39.618 .449 & $51 \%$ \\
\hline Piraquara & 20.293 .347 & 27.449 .279 & 46.246 .969 & $128 \%$ \\
\hline Colombo & 39.176 .339 & 51.892 .268 & 58.419 .778 & $49 \%$ \\
\hline Fazenda Rio Grande & 14.211 .137 & 20.604 .977 & 23.660 .414 & $66 \%$ \\
\hline Almirante Tamandaré & 18.845 .631 & 24.258 .730 & 25.110 .918 & $33 \%$ \\
\hline
\end{tabular}

Fonte: FNDE (2003, 2007, 2010). Elaborado pela autora.

Oito dos doze municípios do PARMC cresceram mais de $50 \%$ os gastos em MDE; o município de Piraquara registrou o maior crescimento, chegando a dobrar o seu gasto em 2010, quando comparado ao ano de 2003. Parte desse gasto é visto no esforço de ampliação das matrículas na rede municipal, pois é o único município do grupo dos mais pobres que fez essa alavanca nas matrículas.

Os municípios de Araucária, Curitiba, Colombo e Almirante Tamandaré apresentaram as menores taxas de crescimento acumulado na MDE. Araucária e Curitiba, municípios ricos, permaneceram crescendo 
nas matrículas da rede municipal, ainda que estivessem entre os com menores taxas de crescimento do gasto em MDE. Já em Colombo e Almirante Tamandaré, municípios mais pobres, verificou-se a redução das matrículas na rede municipal, mas com crescimento contínuo no gasto em MDE. Em Almirante Tamandaré, o decréscimo nas matrículas foi de $17 \%$, o que representou uma redução de 2.125 vagas na rede municipal ante o crescimento de 14.927 habitantes, manifestando a precariedade da rede municipal e seu atendimento.

Na Tabela 7, é possível analisar o movimento do gasto em MDE por matrículas da rede municipal, em valores reais atualizados pelo INPC de dezembro de 2010.

Tabela 7 - Gastos em Manutenção e Desenvolvimento do Ensino, por Matrícula na Rede Municipal, em Valores Reais Corrigidos pelo Índice Nacional de Preços ao Consumidor (INPC - Dez. 2010) - 2003, 2007 e 2010

\begin{tabular}{|l|c|c|c|c|}
\multicolumn{4}{|c|}{ Gasto em MDE por matrícula na rede municipal } & $\begin{array}{c}\text { Taxa de } \\
\text { Crescimento } \\
\text { Acumulado }\end{array}$ \\
\hline Municípios mais ricos & 2003 & 2007 & 2010 & \\
\hline Araucária & 3.273 & 4.047 & 3.792 & $16 \%$ \\
\hline Quatro Barras & 2.118 & 3.597 & 3.744 & $77 \%$ \\
\hline São José dos Pinhais & 2.387 & 2.666 & 4.077 & $71 \%$ \\
\hline Curitiba & 3.706 & 3.805 & 4.942 & $33 \%$ \\
\hline Municípios intermediários & & & & \\
\hline Pinhais & 2.508 & 2.728 & 3.757 & $50 \%$ \\
\hline Campo Magro & 1.929 & 2.439 & 3.086 & $60 \%$ \\
\hline Campina Grande do Sul & 1.767 & 2.379 & 4.281 & $142 \%$ \\
\hline Municípios mais pobres & & & & \\
\hline Campo Largo & 2.107 & 2.419 & 3.221 & $53 \%$ \\
\hline Piraquara & 2.129 & 2.678 & 4.584 & $115 \%$ \\
\hline Colombo & 1.505 & 2.011 & 2.286 & $52 \%$ \\
\hline Fazenda Rio Grande & 1.413 & 2.203 & 2.482 & $76 \%$ \\
\hline Almirante Tamandaré & 1.542 & 2.170 & 2.487 & $61 \%$ \\
\hline
\end{tabular}

Fonte: FNDE (2003, 2007, 2010); Inep/MEC (2003, 2007, 2010). Elaborado pela autora.

O gasto aluno/ano da rede municipal no PARMC foi maior que $50 \%$ em 11 dos 12 municípios. Araucária foi o único município com o percentual da taxa de crescimento acumulado inferior a 50\% e o único que apresentou um decréscimo do valor do gasto aluno/ano nos períodos analisados (2007-2010). No ano de 2007, o valor do gasto aluno/ano foi duas vezes maior que o de outros municípios, como Colombo e Almirante Tamandaré.

Campina Grande do Sul e Piraquara apresentaram as maiores taxas de crescimento acumulado do gasto aluno/ano, acima de 100\%. Em Campina Grande do Sul, o crescimento chegou a ser quase três vezes maior no 
gasto aluno/ano, mas não expressou esse gasto nas matrículas da rede municipal, pois registrou-se o encolhimento da rede pelo decréscimo de 22\% nas matrículas municipais. Piraquara segue conforme já especificado: único município do grupo dos mais pobres com esforço na ampliação de matrículas.

Todos os municípios do PARMC apresentaram valores com gasto aluno/ano superiores ao valor mínimo aluno/ano estadual e nacional em todos os anos analisados do corte desta pesquisa. Segundo o Fundef, para o ano de 2003, o valor mínimo aluno/ano ${ }^{7}$ era de $\mathrm{R} \$ 462$, que, em valores reais corrigidos pelo INPC de dezembro de 2010, expressa a quantia de R \$ 660,83. Para os anos de 2007 e 2010, os valores mínimos dos gastos aluno/ano analisados foram do Estado do Paraná, que apresentou, segundo os dados estatísticos do valor aluno/ano e da receita anual prevista, as quantias de $\mathrm{R} \$ 1.272,83$ e $\mathrm{R} \$ 1.517,08$, respectivamente (FNDE, 2007; 2008). Em valores reais, o ano de 2007 apresentou o valor mínimo do gasto aluno/ano no Estado do Paraná de R\$ 1.516,88. Indireta ou diretamente, o valor do gasto aluno/ano impactou na remuneração dos professores do magistério público, pois o cálculo da remuneração parte do conjunto de gastos em MDE (Brasil, 1996b).

\section{Fundef e Fundeb}

Para analisar o movimento do Fundef e, depois, do Fundeb, as informações trabalhadas foram obtidas no FNDE, no relatório municipal do Siope.

Prosseguindo no encaminhamento do corte da pesquisa, no Fundef foi analisado o ano de 2003, e, no Fundeb, os anos de 2007 e 2010, sendo o último ano de análise também pertinente ao PSPN.

O Gráfico 1 demonstra o movimento do Fundef/Fundeb nos cortes dos anos de 2003, 2007 e 2010, segundo o ganho/perda com esse mecanismo legal na receita da educação dos municípios do PARMC.

O movimento do Gráfico 1 nos anos destacados demonstra que há municípios que só perderam com o fundo, outros que somente ganharam e outros que, ano perderam, ano ganharam. Segundo esse movimento, é possível classificar os municípios do PARMC, conforme Tabela 8.

No movimento dos municípios que perdem/ganham com o Fundef/ Fundeb, incluem-se os mais ricos e industrializados, que, ao contribuírem com o fundo, passam mais recursos do que recebem no repasse. Araucária, o município mais rico do PARMC segundo sua receita per capita, é o único que sempre perdeu com o fundo, tendo menos prejuízo no intervalo de 2007-2010, o que pode ter relação com a redução no gasto em MDE nesse mesmo período, já que os recursos que não retornaram ao município, e devido aos efeitos da política de fundos, foram contabilizados como investimento para o cálculo da vinculação orçamentária, ou seja, caracterizaram-se como gastos em MDE.
7 Valor nacional mínimo aluno/ ano promulgado pelo Decreto ${ }^{\circ}$ 4.861 de 2003. 


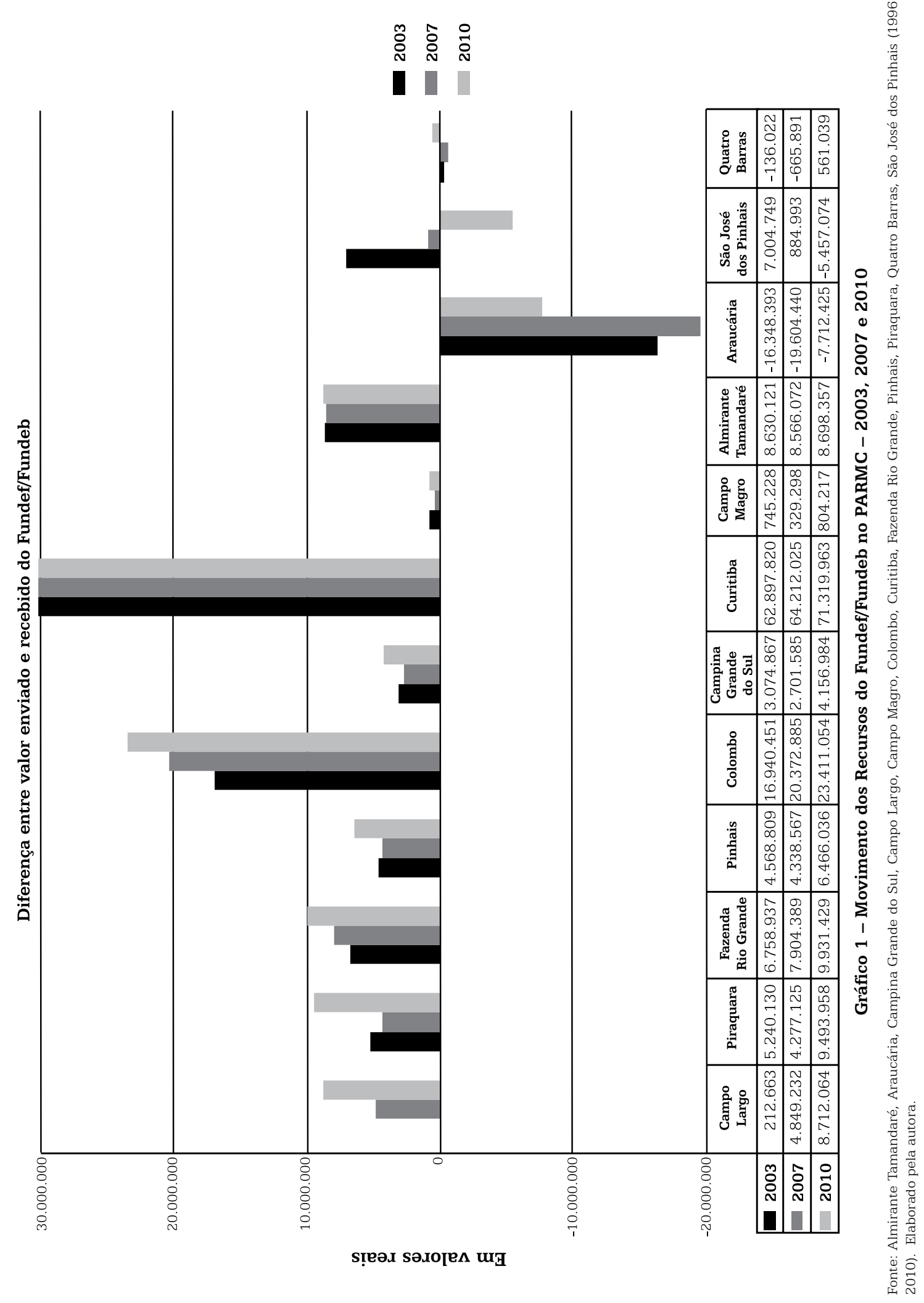




\begin{abstract}
Tabela 8 - Classificação dos Municípios que Perdem/Ganham com o Fundef/Fundeb e dos que Ganham, em Valores Reais Corrigidos pelo Índice Nacional de Preços ao Consumidor (INPC - Dez. 2010) - 2003, 2007 e 2010
\end{abstract}

\begin{tabular}{|c|c|c|c|}
\hline \multicolumn{4}{|c|}{ Municípios que perdem/ganham com o Fundef/Fundeb } \\
\hline & 2003 & 2007 & 2010 \\
\hline Araucária & -16.348 .393 & -19.604 .440 & -7.712 .425 \\
\hline Quatro Barras & -136.022 & -665.891 & 561.039 \\
\hline São José dos Pinhais & 7.004 .749 & 884.993 & -5.457 .074 \\
\hline \multicolumn{4}{|c|}{ Municípios que ganham com o Fundef/Fundeb } \\
\hline & 2003 & 2007 & 2010 \\
\hline Campo Largo & 212.663 & 4.849 .232 & 8.712 .064 \\
\hline Campo Magro & 745.228 & 329.298 & 804.217 \\
\hline Campina Grande do Sul & 3.074 .867 & 2.701 .585 & 4.156 .984 \\
\hline Pinhais & 4.568 .809 & 4.338 .567 & 6.466 .036 \\
\hline Piraquara & 5.240 .130 & 4.277 .125 & 9.493 .958 \\
\hline Almirante Tamandaré & 8.630 .121 & 8.566 .072 & 8.698 .357 \\
\hline Colombo & 16.940 .451 & 20.372 .885 & 23.411 .054 \\
\hline Curitiba & 62.897 .820 & 64.212 .025 & 71.319 .963 \\
\hline Fazenda Rio Grande & 6.758 .937 & 7.904 .389 & 9.931 .429 \\
\hline
\end{tabular}

Fonte: FNDE $(2003,2007,2010)$. Elaborado pela autora.

Quatro Barras registrou perda com o Fundef. Com o Fundeb começou perdendo, depois, chegou a ganhar no ano de 2010. No período de análise desta pesquisa, esse município teve crescimento da receita e da população, o que expressa, no intervalo de 2007-2010, o não acompanhamento proporcional, uma vez que sua receita per capita sofreu uma queda nesse mesmo período, porém, apresentou a taxa de crescimento acumulado de gasto em MDE significativa de 26\%, não tendo relação com as matrículas. Verificou-se que o aumento populacional pode ter refletido sobre o ganho com o Fundeb em 2010, mas não como o investimento desse recurso na ampliação de matrículas e remuneração de professores, conforme Tabela 7, podendo ter sido aplicado em outras estruturas do ensino fundamental.

São José dos Pinhais ampliou sua receita municipal expressivamente no período do Fundeb, no intervalo de 2007-2010, assim como ampliou o gasto em MDE e as matrículas, refletindo sobre a perda com o fundo nesse intervalo. No período do Fundef, o município ganhou. Com o seu crescimento econômico, assim como Araucária, passou também a perder com o fundo, em razão de seu incremento econômico industrial.

Os outros nove municípios do PARMC sempre ganharam com o fundo nos intervalos de anos analisados, tanto com o Fundef quanto com o Fundeb, como se pode visualizar na Tabela 8, em consonância com a política de financiamento da educação do fundo por matrículas, 
minimizando as desigualdades sociais na educação, segundo seus recursos. Somente Curitiba, constituinte do grupo dos mais ricos, ganhou com o fundo, devido a sua grande rede municipal. Todos os outros municípios que ganharam com o fundo fazem parte do grupo dos intermediários ou dos mais pobres.

O município de Campo Largo foi o que apresentou maior ganho com a política de fundos, principalmente no intervalo de 2003-2007. Ao analisar o período de 2003 a 2010, pode-se dizer que esse município chegou a ganhar quarenta vezes mais com o Fundeb em 2010. Esse também é um município de economia agrícola.

\section{Remuneração inicial dos professores}

A análise da remuneração inicial dos professores considera as informações pertinentes à tabela salarial para os professores com ingresso na carreira do magistério com nível superior em licenciatura plena, em jornada de trabalho de 20 horas semanais.

A seguir, a Tabela 9 demonstra o movimento da remuneração inicial dos professores da rede municipal, disposto segundo o critério do município que apresentou maior taxa de crescimento acumulado. Os municípios de São José dos Pinhais e Colombo apresentam lacunas pela ausência de informação nos respectivos anos e nos subsequentes.

Tabela 9 - Remuneração Inicial dos Professores do PARMC, em Valores Reais Corrigidos pelo Índice Nacional de Preços ao Consumidor (INPC - Dez. 2010) - 2003, 2007 e 2010

\begin{tabular}{|l|r|r|r|r|}
\hline \multicolumn{1}{|c|}{ Município } & 2003 & 2007 & 2010 & $\begin{array}{c}\text { Taxa de } \\
\text { crescimento } \\
\text { acumulado }\end{array}$ \\
\hline Campina Grande do Sul * & 566,43 & 931,10 & 873,67 & $54 \%$ \\
\hline Araucária & 1077,57 & 1140,41 & 1566,14 & $45 \%$ \\
\hline Curitiba & 792,47 & 889,23 & 1126,68 & $42 \%$ \\
\hline Fazenda Rio Grande & 441,81 & 554,16 & 614,61 & $39 \%$ \\
\hline Pinhais & 1007,49 & 1287,84 & 1295,85 & $29 \%$ \\
\hline Campo Magro & 630,68 & 834,26 & 764,67 & $21 \%$ \\
\hline Almirante Tamandaré & 637,17 & 653,18 & 742,92 & $17 \%$ \\
\hline São José dos Pinhais & 1119,76 & & 1278,08 & $14 \%$ \\
\hline Campo Largo & 661,66 & 709,01 & 688,47 & $4 \%$ \\
\hline Colombo & & 798,53 & 813,16 & $2 \%$ \\
\hline Quatro Barras & 813,87 & 825,13 & 811,17 & $0 \%$ \\
\hline Piraquara * & 1158,10 & 1117,79 & 906,83 & $-22 \%$ \\
\hline
\end{tabular}

* Município com ausência de informação nos anos de corte, utilizando-se, portanto, o ano subsequente. Campina Grande do Sul (2008) e Piraquara (2004).

Fonte: Almirante Tamandaré, Araucária, Campina Grande do Sul, Campo Largo, Campo Magro, Colombo, Curitiba, Fazenda Rio Grande, Pinhais, Piraquara, Quatro Barras e São José dos Pinhais (2003, 2007, 2010). Elaborado pela autora. 
A base de cálculo da taxa de crescimento acumulado para o município de Colombo foi o intervalo de 2007-2010, devido à ausência da tabela salarial municipal do ano de 2003. No município de São José dos Pinhais, também temos uma lacuna no ano de 2007, por ausência de informação.

Na análise da remuneração inicial dos professores da rede municipal, em valores reais, verificou-se a heterogeneidade no movimento da remuneração nos intervalos selecionados.

No movimento crescente da remuneração inicial dos professores de 2003-2007 e, depois, decrescente em 2007-2010, destacaram-se Campina Grande do Sul, Campo Magro, Campo Largo e Quatro Barras. Enfatiza-se que Quatro Barras está no grupo dos municípios mais ricos, Campina Grande do Sul e Campo Magro, no dos intermediários, e Campo Largo, entre os municípios mais pobres.

Em movimento constante de crescente remuneração inicial dos professores tem-se Araucária, Curitiba, Fazenda Rio Grande, Pinhais, Almirante Tamandaré, São José dos Pinhais e Colombo.

Somente o município de Piraquara apresentou o movimento constante de decréscimo na remuneração inicial dos professores da rede municipal.

Campina Grande do Sul foi o município que mostrou o maior percentual na taxa de crescimento acumulado no intervalo de 20032010 e, apesar desse feito, registra, no intervalo de 2007-2010, perda na remuneração em valores reais de $22 \%$ - um retrocesso na valorização do magistério enquanto política de financiamento na remuneração.

Atualmente, as melhores remunerações iniciais aos professores do magistério público municipal no PARMC estão em Araucária, Pinhais, São José dos Pinhais e Curitiba. Desses, apenas São José dos Pinhais ainda tem o Estatuto do Servidor Público regendo o magistério público, não tendo plano de carreira, cargos e remuneração do magistério público vigente.

Os municípios com as piores remunerações iniciais aos professores na rede municipal são Fazenda Rio Grande, Campo Largo, Almirante Tamandaré e Campo Magro.

Na configuração da remuneração inicial aos professores pela receita per capita municipal foi possível constatar que a concentração das melhores remunerações está nos municípios mais ricos, e a concentração das piores, nos mais pobres.

Quatro Barras apresentou o valor de remuneração inicial dos professores abaixo do perfil de sua classificação na receita per capita municipal e sem crescimento acumulado na remuneração, como já citado, colocando-o, segundo as matrículas e a remuneração inicial dos professores, no grupo dos municípios intermediários. Pinhais se destacou por pertencer ao grupo dos municípios intermediários e por sua remuneração inicial dos professores e expansão das matrículas municipais, colocando-o no patamar dos municípios mais ricos.

Percebeu-se o esforço dos municípios mais pobres na remuneração inicial dos professores, apresentando valores semelhantes aos dos 
${ }^{8}$ Valor do PSPN em 2010 era de $\mathrm{R} \$ 1024,67$, para jornada de 40 horas semanais. Para a jornada de 20 horas semanais, o valor era de $\mathrm{R} \$ 512,33$ intermediários no ano de 2010. Fazenda Rio Grande e Campo Largo foram os municípios do grupo dos mais pobres e com as piores remunerações, ainda que apresentassem taxa de crescimento acumulado da remuneração de forma significativa, 39\% e 17\%, respectivamente. Apesar de apresentarem a menor remuneração inicial dos professores, o aumento do gasto em MDE em Fazenda Rio Grande poderia ser explicado pelo esforço na composição do valor da remuneração dos professores, porém, o patamar ainda é muito baixo para a remuneração inicial dos docentes no PARMC.

Os municípios com as maiores taxas de crescimento acumulado em remuneração foram Araucária, Curitiba, Campina Grande do Sul e Fazenda Rio Grande.

Em Araucária e Curitiba, municípios mais ricos do PARMC, estão os sindicatos mais organizados dos profissionais da educação, que expressam com esforço as reivindicações no espaço da política, podendo ser este também o impacto sobre a remuneração inicial dos professores nesses municípios, que se destacam por serem as maiores no PARMC.

Seguindo a mesma lógica de Fazenda Rio Grande, o município de Campina Grande do Sul apresentou uma das menores remunerações iniciais dos professores, porém, esforçou-se na composição dessa remuneração ao apresentar o maior percentual da taxa do crescimento acumulado em remuneração dos docentes no PARMC, 54\%.

Analisando se os municípios do PARMC estão praticando o mínimo do PSPN $^{8}$ na remuneração inicial dos professores, segundo a proporcionalidade de carga horária de trabalho, constatou-se o cumprimento da lei.

A média da remuneração inicial dos professores, no ano de 2010, fez um corte, em que os municípios que conseguiram estar acima da média foram na maioria os do grupo dos mais ricos: Araucária, São José dos Pinhais e Curitiba, excetuando Pinhais, do grupo dos intermediários, com remuneração inicial acima da média.

Ainda sobre a remuneração dos professores, esta é parte constituinte do custo aluno, que, segundo previsto na legislação do País, permeia a garantia de padrão de qualidade (Brasil. Constituição, 1988; Brasil. Lei $\left.n^{\circ} 9.424,1996\right)$. Estudos sobre a definição de referenciais de Custo Aluno-Qualidade Inicial (CAQi) para a educação básica apresentaram a proposta de que 73\% no mínimo do gasto em MDE deveria ser destinado à remuneração dos professores (Carreira; Pinto, 2007).

O Gráfico 2 demonstra o percentual do gasto aluno/ano aplicado pelos municípios do PARMC na remuneração inicial dos professores, para o ano de 2010.

O patamar ideal para o CAQi está bem aquém da realidade apresentada pelos municípios quanto ao percentual do custo aluno/ano aplicado na remuneração inicial dos professores no PARMC. Apenas para um exercício: se o salário final dos professores fosse o dobro do salário inicial, teríamos um acréscimo de 50\% no impacto da remuneração no gasto aluno/ano. Assim, considerando, por exemplo, o caso de Araucária, o impacto saltaria de $41 \%$ para $61,5 \%$, ainda abaixo do que seria esperado, segundo os cálculos para o CAQi. 
Análise do Gasto aluno/ano em Remuneração Inicial dos Professores no PARMC

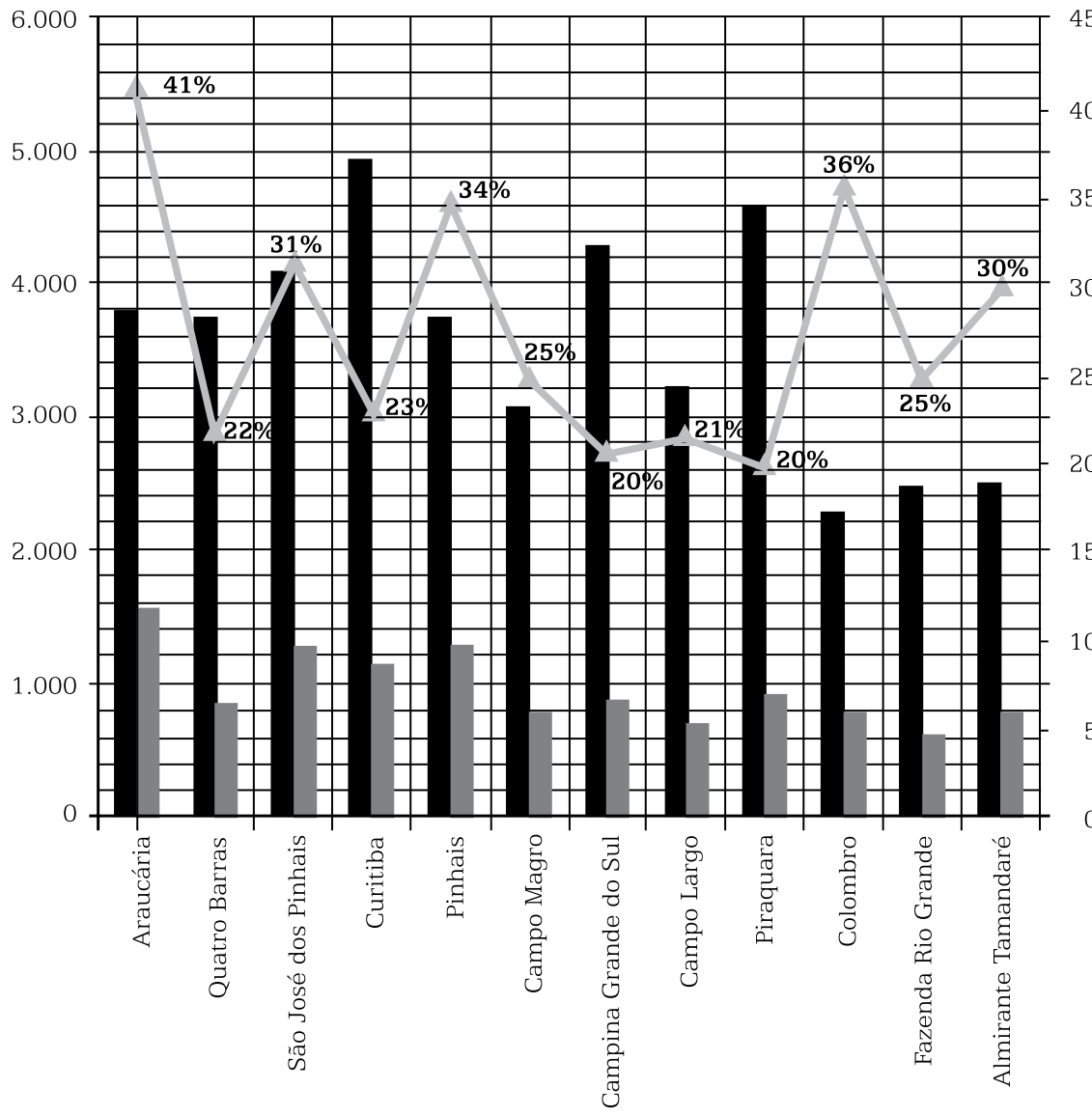

$45 \%$

$40 \%$

Gasto (2010) $35 \%$ $30 \%$ 25\% Professores (2010)

$20 \%$ $15 \%=$ Percentual gasto à Remuneração Inicial dos Professores do valor aluno/ano

\section{Gráfico 2 - Movimento do Gasto Aluno/Ano, da Remuneração Inicial dos Professores e Percentual do Valor do Gasto Aluno/Ano Utilizado em Remuneração}

Fonte: FNDE (2010); Inep/MEC (2010); Almirante Tamandaré, Araucária, Campina Grande do Sul, Campo Largo, Campo Magro, Colombo, Curitiba, Fazenda Rio Grande, Pinhais, Piraquara, Quatro Barras e São José dos Pinhais (2010). Elaborado pela autora.

A maior remuneração inicial dos professores foi encontrada justamente no município que aplicou o maior percentual do gasto aluno/ ano em remuneração - Araucária.

Após Araucária, os municípios de Colombo, Pinhais e Curitiba foram os que apresentaram os maiores percentuais do gasto aluno/ano em remuneração dos professores, 36\%, 34\% e 31\%, respectivamente. Pinhais e Curitiba ficaram entre os municípios com maiores remunerações iniciais dos professores. Já Colombo, como parte dos municípios mais pobres do PARMC, apresentou remuneração inicial correspondente a esse grupo.

O percentual de 73\% do gasto em MDE foi com pessoal, entre eles, a remuneração dos professores. Esta pesquisa contempla a análise da remuneração inicial dos professores, porém, ante os dados do Gráfico 2 e o que os especialistas do financiamento da educação explanam a favor de 
uma educação de qualidade, é possível argumentar que há pouco esforço pela valorização da remuneração por parte dos municípios do PARMC.

A Tabela 10 registra o panorama da remuneração inicial dos professores, segundo proposto neste artigo.

Tabela 10 - Resumo dos Dados do PARMC Pertinentes à Remuneração Inicial dos Professores do Magistério Público do Ensino Fundamental, ao Fundef/ Fundeb e às Matrículas, segundo a Classificação da Receita Per Capita Municipal

\begin{tabular}{|c|c|c|c|c|c|c|}
\hline \multicolumn{4}{|c|}{$\begin{array}{l}\text { Remuneração inicial dos professores da rede } \\
\text { municipal do PARMC }\end{array}$} & \multirow{2}{*}{$\begin{array}{c}\text { Perde/Ganha } \\
\text { Fundef/ } \\
\text { Fundeb } \\
2003-2010\end{array}$} & \multirow{2}{*}{$\begin{array}{c}\text { Segundo } \\
\text { o Gasto } \\
\text { em MDE } \\
2010\end{array}$} & \multirow{2}{*}{$\begin{array}{l}\text { Matrículas } \\
\text { 2003-2010 }\end{array}$} \\
\hline Municípios & 2003 & 2007 & 2010 & & & \\
\hline \multicolumn{7}{|l|}{ Mais ricos } \\
\hline Araucária & 1.078 & 1.140 & 1.566 & Perde & $5^{\circ}$ & Amplia \\
\hline Quatro Barras & 814 & 825 & 811 & Perde/Ganha & $7^{\circ}$ & Reduz/Amplia \\
\hline São José dos Pinhais & 1.120 & & 1.278 & Perde & $4^{\circ}$ & Amplia \\
\hline Curitiba & 792 & 889 & 1.127 & Ganha & $1^{\circ}$ & Amplia \\
\hline \multicolumn{7}{|l|}{ Intermediários } \\
\hline Pinhais & 1.007 & 1.288 & 1.296 & Ganha & $6^{\circ}$ & Amplia \\
\hline Campo Magro & 631 & 834 & 765 & Ganha & $9^{\circ}$ & Amplia/Reduz \\
\hline Campina Grande do Sul & 566 & 931 & 874 & Ganha & $3^{\circ}$ & Reduz \\
\hline \multicolumn{7}{|l|}{ Mais pobres } \\
\hline Campo Largo & 662 & 709 & 688 & Ganha & $8^{\circ}$ & Amplia/Reduz \\
\hline Piraquara & 1.158 & 1.118 & 907 & Ganha & $2^{\circ}$ & Amplia/Reduz \\
\hline Colombo & & 799 & 813 & Ganha & $12^{\circ}$ & Reduz \\
\hline Fazenda Rio Grande & 442 & 554 & 615 & Ganha & $11^{\circ}$ & Reduz/Amplia \\
\hline Almirante Tamandaré & 637 & 653 & 743 & Ganha & $10^{\circ}$ & Reduz \\
\hline
\end{tabular}

Fonte: FNDE (2003, 2007, 2010); Inep/MEC (2003, 2007, 2010); Almirante Tamandaré, Araucária, Campina Grande do Sul, Campo Largo, Campo Magro, Colombo, Curitiba, Fazenda Rio Grande, Pinhais, Piraquara, Quatro Barras, São José dos Pinhais (2003, 2007, 2010). Elaborado pela autora.

Embora pertença ao grupo dos municípios mais ricos, segundo sua receita per capita, Quatro Barras pode ser considerado singular em suas análises, pois sua remuneração é semelhante à dos municípios intermediários/pobres. No período do Fundef, Quatro Barras perdeu recursos com o fundo, mas obteve ganho com o Fundeb. No ranking dos municípios do PARMC, em gasto na MDE, ocupou o sétimo lugar e teve redução das matrículas na vigência do Fundef, ampliando-as com o Fundeb, período também do crescimento populacional.

Pinhais também apresentou particularidades, ao ponto de se assemelhar, segundo suas características, aos municípios mais ricos, exceto pelo fato de ganhar com o Fundef/Fundeb. 
No grupo dos mais ricos, geralmente estão concentradas as melhores remunerações, os municípios que perderam com o Fundef/Fundeb, os que mais gastaram em MDE e os que ampliaram suas matrículas municipais.

Os municípios pertencentes ao grupo intermediário e aos mais pobres geralmente ganharam com o Fundef/Fundeb ao apresentarem o movimento de ampliação e redução das matrículas municipais e remuneração inicial dos professores na faixa de $\mathrm{R} \$ 688$ a $\mathrm{R} \$$ 907, no ano de 2010.

Os municípios mais pobres possuem as piores remunerações, os menores gastos em MDE e sempre ganharam com o Fundef/ Fundeb e em movimento de redução das matrículas, com exceção de Fazenda Rio Grande, que, no período de 2007-2010, ampliou as matrículas na rede municipal.

O contexto municipal da remuneração inicial dos professores no PARMC, sintetizado pela Tabela 11, permite a análise da taxa de crescimento acumulado dos itens.

Tabela 11 - Síntese do Contexto e Remuneração Inicial no PARMC, segundo as Taxas de Crescimento Acumulado

\begin{tabular}{|c|c|c|c|c|c|c|}
\hline Municipio & $\begin{array}{c}\text { Taxa de } \\
\text { Crescimento } \\
\text { Populacional }\end{array}$ & $\begin{array}{c}\text { Taxa de } \\
\text { Renda Per } \\
\text { Capita }\end{array}$ & $\begin{array}{c}\text { Taxa de } \\
\text { Crescimento } \\
\text { Matrículas }\end{array}$ & $\begin{array}{c}\text { Taxa de } \\
\text { Crescimento } \\
\text { Gasto MDE }\end{array}$ & $\begin{array}{c}\text { Taxa de } \\
\text { Crescimento } \\
\text { Gasto Aluno/ } \\
\text { Ano }\end{array}$ & $\begin{array}{c}\text { Taxa de } \\
\text { Crescimento } \\
\text { Remuneração }\end{array}$ \\
\hline Araucária & $26 \%$ & $27 \%$ & $9 \%$ & $26 \%$ & $16 \%$ & $45 \%$ \\
\hline Quatro Barras & $23 \%$ & $32 \%$ & $0 \%$ & $76 \%$ & $77 \%$ & $0 \%$ \\
\hline $\begin{array}{l}\text { São José dos } \\
\text { Pinhais }\end{array}$ & $29 \%$ & $130 \%$ & $9 \%$ & $86 \%$ & $71 \%$ & $14 \%$ \\
\hline Curitiba & $10 \%$ & $39 \%$ & $2 \%$ & $36 \%$ & $33 \%$ & $42 \%$ \\
\hline Pinhais & $14 \%$ & $73 \%$ & $17 \%$ & $76 \%$ & $50 \%$ & $29 \%$ \\
\hline Campo Magro & $22 \%$ & $41 \%$ & $-1 \%$ & $59 \%$ & $60 \%$ & $21 \%$ \\
\hline $\begin{array}{l}\text { Campina } \\
\text { Grande do Sul }\end{array}$ & $12 \%$ & $52 \%$ & $-22 \%$ & $88 \%$ & $142 \%$ & $54 \%$ \\
\hline Campo Largo & $21 \%$ & $48 \%$ & $-1 \%$ & $51 \%$ & $53 \%$ & $4 \%$ \\
\hline Piraquara & $28 \%$ & $74 \%$ & $6 \%$ & $128 \%$ & $115 \%$ & $-22 \%$ \\
\hline Colombo & $16 \%$ & $69 \%$ & $-2 \%$ & $49 \%$ & $52 \%$ & $2 \%$ \\
\hline $\begin{array}{l}\text { Fazenda Rio } \\
\text { Grande }\end{array}$ & $30 \%$ & $58 \%$ & $-5 \%$ & $66 \%$ & $76 \%$ & $39 \%$ \\
\hline $\begin{array}{l}\text { Almirante } \\
\text { Tamandaré }\end{array}$ & $17 \%$ & $71 \%$ & $-17 \%$ & $33 \%$ & $61 \%$ & $17 \%$ \\
\hline
\end{tabular}

Fonte: FNDE (2003, 2007, 2010); Inep/MEC (2003, 2007, 2010); Almirante Tamandaré, Araucária, Campina Grande do Sul, Campo Largo, Campo Magro, Colombo, Curitiba, Fazenda Rio Grande, Pinhais, Piraquara, Quatro Barras, São José dos Pinhais (2003, 2007, 2010). Elaborado pela autora.

Entre os municípios mais ricos, Araucária é o que tem maior taxa de crescimento da remuneração inicial, ainda que haja crescimento da matrícula e forte crescimento populacional, parece existir certa prioridade 
de gastos com remuneração - é um caso que indica a necessidade de outros estudos.

No grupo dos municípios intermediários, Campina Grande do Sul apresentou queda de matrícula, crescimento de gastos em MDE e a maior taxa de gasto aluno/ano, o que poderia explicar a possibilidade de esforço de ampliação dos salários, acima, inclusive, do grupo de municípios ricos.

Piraquara apresentou uma relação inversa entre crescimento da matrícula, gasto aluno/ano e descréscimo na remuneração, tornando possível levantar-se a hipótese de que as pressões sobre a oferta expandiram a rede, em detrimento da valorização monetária dos professores.

Assim, o que explicaria a remuneração inicial dos professores no PARMC seria a tensão da política municipal e suas priorizações orçamentárias, além da organização dos trabalhadores do magistério, expressa nas pressões dos sindicatos.

É possível verificar, no transcorrer desta dissertação, uma relação não linear da política de fundos com a remuneração inicial dos professores, considerando que os municípios que perderam com os fundos foram os que possuíram as melhores e maiores remunerações no PARMC - Araucária e Pinhais. Piraquara obteve maior ganho com os fundos e não constou entre os municípios com melhores remunerações iniciais aos professores. A relação que toma expressão nessa investigação é que nos municípios mais ricos foram encontrados os melhores salários - com exceção de Quatro Barras, cuja expansão da riqueza no município não acompanhou as melhores remunerações iniciais dos professores -, e, nos municípios mais pobres, as piores remunerações iniciais.

No PARMC, tem-se pouco impacto do PSPN sobre a remuneração inicial dos professores, pois, considerando-se a proporcionalidade de 20 horas na jornada de trabalho, todos os municípios já praticavam o piso no ano de 2009. A perspectiva de contribuição dessa lei está na hora atividade, que, para a carga de trabalho de 20 horas semanais, corresponde ao percentual de 33,3\% em hora atividade, conforme previsto pela Lei do PSPN, mas ainda em luta pela sua concretização. ${ }^{9}$

Segundo a remuneração inicial dos professores no PARMC, o que se constatou nos municípios mais pobres foi a baixa atratividade da remuneração para o ingresso na carreira de professor da rede municipal, pois as maiores remunerações encontram-se nos municípios mais ricos.

\section{Considerações finais}

$\mathrm{Na}$ questão do financiamento da remuneração dos professores do magistério público, o Fundef e o Fundeb se destacaram como mecanismos de regulação, principalmente por subvincularem o percentual de 60\% do fundo à remuneração docente. Para analisar os efeitos do Fundef/Fundeb, esta dissertação se propôs a coletar tabelas salariais com remuneração 
inicial dos professores do magistério público da rede municipal. No entanto, a primeira complexidade evidenciada foi a dificuldade de se obter informações, as quais deveriam ser disponibilizadas pela política de transparência municipal.

Fatores como a burocracia generalizada na requisição das informações públicas ante as prefeituras ou até mesmo a ausência dessas informações organizadas, bem como a fraca articulação da classe dos professores, enquanto organização dos sindicatos no PARMC, também dificultou a análise.

As políticas de fundos atuaram como mecanismo de regulação da remuneração dos professores ao estabelecerem o percentual mínimo de $60 \%$ à remuneração e, como carregam em seu título na letra da lei, vislumbravam a valorização do magistério público e/ou dos profissionais da educação.

Dos 12 municípios do PARMC, 11 apresentaram valorização da remuneração inicial dos professores quanto ao percentual de crescimento acumulado. Somente Piraquara apresentou um processo crescente de desvalorização, expressando o percentual de $-22 \%$.

O município com maior crescimento da remuneração foi Campina Grande do Sul, com 54\%, que sempre ganhou com os fundos, mas seu esforço de pagar R \$ 874, em 2010, ao professor em início de carreira, ainda resultou em uma remuneração inferior à de Piraquara, R\$ 907 - município com desvalorização de $22 \%$ no crescimento acumulado da remuneração.

A melhor remuneração inicial dos professores destacou-se em Araucária, com o pagamento de R $\$ 1.566$ ao professor ingressante no ano de 2010, numa relação inversa de sempre perder com o fundo.

A luta histórica dos professores do magistério na consolidação do PSPN foi concretizada, em lei, no ano de 2008, 181 anos depois da última vinculação em lei nacional de remuneração e valor pelo DecretoLei Imperial de 1827. Foi instituída com embates acerca de suas especificidades, como a questão do tempo da hora atividade e hora/aula e por considerar o piso como vencimento inicial. Finalmente, em 2011, ela foi aprovada em sua totalidade, sendo considerada constitucional.

Dada a realidade da análise das políticas de fundo e do PSPN, as perspectivas estão na execução da hora atividade de $20 \%$ da jornada de trabalho, no ganho como valorização dos profissionais da educação.

Antes mesmo da política do PSPN, no PARMC, todos os municípios já praticavam o piso salarial aos professores do magistério público, porém, nem todos atualmente são regidos pelo plano de carreira e remuneração do magistério, como o caso de Quatro Barras e São José dos Pinhais. A estes, a Lei do PSPN estabeleceu o prazo de adequação de até 31 de dezembro de 2009, período já expirado.

Evidentemente, o que se constata é que a ausência de fiscalização da regulação das leis favorece precedentes aos municípios, tanto no tempo quanto na forma, em relação ao atendimento às leis supranacionais. Para além da política nacional, a política municipal, assim como o contexto da economia e educação nos municípios do PARMC, contribui na configuração da remuneração inicial dos professores do magistério público. 
Verifica-se a ausência de políticas constantes de reposição inflacionária sobre a remuneração inicial dos professores, refletindo na corrosão da remuneração e seus impactos sobre as tabelas salariais e sobre os planos de carreira.

Como afirma Arelaro (2007) acerca do valor da remuneração dos professores, bastava cumprirem o que já estava disposto na Constituição de 1988 quanto ao salário do trabalhador: um salário que dê condições para vestuário, alimentação, habitação e educação.

O Fundef/Fundeb tinha em sua proposição a redução das desigualdades entre as regiões na questão do financiamento da educação, e, conforme Monlevade (2000), isso ocorreu na esfera estadual, onde, no período do Fundef, havia professores que possuíam remuneração inferior ao salário mínimo. No PARMC, o piso da remuneração inicial dos professores com a jornada de trabalho de 20 horas semanais tem a característica de estar sempre acima do salário mínimo, e, desde a implantação do PSPN, os valores também ficam acima. Mas enquanto redução das desigualdades entre gasto em MDE e remuneração inicial dos professores, as discrepâncias permanecem. A lógica predominante no PARMC é: municípios mais ricos com as melhores remunerações, e municípios mais pobres com as piores remunerações, ainda que estes últimos ganhem com o fundo da política educacional - Fundef/Fundeb.

Em grande parte do PARMC, os municípios exigem o nível superior completo para ingresso na carreira de professor no magistério público municipal, mas as remunerações ofertadas a este profissional não são atrativas ao esforço acadêmico.

\section{Referências (a)}

ARELARO, L.G.R. FUNDEF: uma avaliação preliminar dos dez anos de sua implantação. In: REUNIÃO ANUAL DA ANPED, 30., 2007, Caxambu. Anais Trabalhos - GT05 - Estado e Política Educacional. Caxambu: Anped, 2007. Disponível em: < http://www.anped.org.br/ reunioes/30ra/trabalhos/GT05-3866--Int.pdf>. Acesso em: 14 abr. 2011.

BRASIL. Instituto Nacional de Estudo e Pesquisas Educacionais Anísio Teixeira (Inep). Sistema de consulta a matrícula do censo escolar 2003. Brasília: Inep, MEC, 2011. Disponível em: <http://portal.inep.gov.br/ basica-censo-escolar-matricula>. Acesso em: 20 out. 2011.

BRASIL. Instituto Nacional de Estudos e Pesquisas Educacionais Anísio Teixeira (Inep). Sistema de consulta a matrícula do censo escolar 2007. Brasília: Inep, MEC, 2011. Disponível em: <http://portal.inep.gov.br/ basica-censo-escolar-matricula>. Acesso em: 20 out. 2011. 
BRASIL. Instituto Nacional de Estudo e Pesquisas Educacionais Anísio Teixeira (Inep). Sistema de consulta a matrícula do censo escolar 2010. Brasília: Inep, MEC, 2011. Disponível em: <http://portal.inep.gov.br/ basica-censo-escolar-matricula >. Acesso em: 20 out. 2011.

CAMARGO, R. B. et al. Financiamento da educação e remuneração docente: um começo de conversa em tempos de piso salarial. Revista Brasileira de Política e Administração da Educação, Porto Alegre, v. 25, n. 2, p. 341-363, maio/ago. 2009.

CARREIRA, D.; PINTO, J. M. R. Custo aluno-qualidade inicial: rumo à educação pública de qualidade no Brasil. São Paulo: Campanha Nacional pelo Direito à Educação, 2007.

FORUM PARANAENSE EM DEFESA DA ESCOLA PÚBLICA, GRATUITA E UNIVERSAL. Relatório da V Sessão Plenária. Foz do Iguaçu, 1991. [Não publicado].

FUNDO NACIONAL DE DESENVOLVIMENTO DA EDUCAÇÃO (FNDE). Relatório Resumido da Execução Orçamentária - RREO - Anexo X da Lei de Responsabilidade Fiscal. Brasília: Siope, FNDE, 2003. Disponível em: <https://www.fnde.gov.br/siope/relatorioRREOMunicipal2006.do>. Acesso em: 20 out. 2011.

FUNDO NACIONAL DE DESENVOLVIMENTO DA EDUCAÇÃO (FNDE). Relatório Resumido da Execução Orçamentária - RREO - Anexo X da Lei de Responsabilidade Fiscal. Brasília: Siope, FNDE, 2007. Disponível em: <https://www.fnde.gov.br/siope/relatorioRREOMunicipal2006.do>. Acesso em: 20 out. 2011.

FUNDO NACIONAL DE DESENVOLVIMENTO DA EDUCAÇÃO (FNDE). Relatório Resumido da Execução Orçamentária - RREO - Anexo X da Lei de Responsabilidade Fiscal. Brasília: Siope, FNDE, 2010. Disponível em: <https://www.fnde.gov.br/siope/relatorioRREOMunicipal2006.do>. Acesso em: 20 out. 2011.

FUNDO NACIONAL DE DESENVOLVIMENTO DA EDUCAÇÃO (FNDE). Valor mínimo nacional por aluno/ano. Brasília:,2010. Disponível em: <www.fnde.gov.br/index.php/fundeb-fundef>. Acesso em: 20 out. 2011.

INSTITUTO BRASILEIRO DE GEOGRAFIA E ESTATÍSTICA (IBGE). Dados do Censo 2010 publicados no Diário Oficial da União do dia 04/11/2010. Brasília: IBGE, 2010. Disponível em: < http://www.ibge. gov.br/home/estatistica/populacao/censo2010/resultados_dou/PR2010. pdf>. Acesso em: 23 out. 2011. 
INSTITUTO BRASILEIRO DE GEOGRAFIA E ESTATÍSTICA (IBGE).

Tabela População residente, por sexo e situação do domicílio, população residente de 10 anos ou mais de idade, total, alfabetizada e taxa de alfabetização, segundo os Municípios. Brasília: IBGE, 2010. Disponível em: <http://www.ibge.gov.br/home/estatistica/populacao/censo2000/ universo.php?tipo $=31 \mathrm{o} /$ tabela13_1.shtm\&uf $=41 \mathrm{>}$. Acesso em: 23 out. 2011.

MONLEVADE, J. A. C. Valorização salarial dos professores: o papel do piso salarial profissional nacional como instrumento de valorização dos professores da educação básica pública. $317 \mathrm{f}$. Tese (Doutorado em Educação) - Universidade Estadual de Campinas, Campinas, 2000.

NOGUCHI, L. F. Políticas para a educação infantil na região metropolitana de Curitiba. 175 f. Dissertação (Mestrado em Educação) - Setor de Educação, Universidade Federal do Paraná, Curitiba, 2009.

NOJIMA, Daniel; MOURA, Rosa; SILVA, Sandra Terezinha da. Dinâmica recente da economia e transformações na configuração espacial da Região Metropolitana de Curitiba. Curitiba: Ipardes, 2004. (Primeira versão, 3).

SANTOS, J. M. T. P. A municipalização do ensino no Estado do Paraná: história, herança e desafios. In: GOUVEIA, Andréa B.; SOUZA, Ângelo R. (Org.). O financiamento da educação e o FUNDEF no Paraná. Curitiba: UFPR, 2001. p. 9-36.

\section{Referências (b) - Documentos Consultados}

ALMIRANTE TAMANDARÉ. Secretaria Municipal da Educação. Tabela do cargo de professor. 2003.

ALMIRANTE TAMANDARÉ. Secretaria Municipal da Educação. Tabela profissionais. 2007.

ALMIRANTE TAMANDARÉ. Secretaria Municipal da Educação. Tabela profissionais. 2010.

ARAUCÁRIA. Secretaria Municipal da Educação. Tabela de vencimentos do magistério. 2003.

ARAUCÁRIA. Secretaria Municipal da Educação. Tabela do magistério. 2007.

ARAUCÁRIA. Secretaria Municipal da Educação. Tabela do magistério. 2010 
BRASIL. Constituição da República Federativa do Brasil. Diário Oficial da União, Brasília, DF, 5 out. 1988. Disponível em: <<http://www. planalto.gov.br/ccivil_03/Constituicao/ConstituicaoCompilado.htm>. Acesso em: 22 ago. 2009.

BRASIL. Decreto-Lei n ${ }^{\circ} 5.452,1^{\circ}$ de maio de 1943. Consolidação das Leis do Trabalho. Diário Oficial da União, Rio de Janeiro, RJ, 9 ago. 1943. Disponível em: <http://www.soleis.com.br/ebooks/0TRABALHISTA.htm>. Acesso em: 20 abr. 2011.

BRASIL. Lei $\mathrm{n}^{\circ}$ 8.112, de 11 de dezembro de 1990. Dispõe sobre o regime jurídico dos servidores públicos civis da União, das autarquias e das fundações públicas federais. Diário Oficial da União, Brasília, DF, 19 abr. 1991. Disponível em: <http://www.planalto.gov.br/ccivil_03/leis/ L8112cons.htm>. Acesso em: 04 maio 2011.

BRASIL. Lei $n^{\circ}$ 9.424, de 24 de dezembro de 1996. Dispõe sobre o Fundo de Manutenção e Desenvolvimento do Ensino Fundamental e de Valorização do Magistério, na forma prevista no art. 60, $\$ 7^{\circ}$, do Ato das Disposições Constitucionais Transitórias, e dá outras providências (Lei do FUNDEF). Diário Oficial da União, Brasília, DF, 23 dez. 1996. Disponível em: < http://www.planalto.gov.br/ccivil_03/leis/L9424.htm>. Acesso em: 22 ago. 2009.

BRASIL. Lei $\mathrm{n}^{\circ}$ 11.494, de 20 de junho de 2007. Regulamenta o Fundo de Manutenção e Desenvolvimento da Educação Básica e de Valorização dos Profissionais da Educação - FUNDEB, de que trata o art. 60 do Ato das Disposições Constitucionais Transitórias; altera a Lei ${ }^{\circ} 10.195$, de 14 de fevereiro de 2001; revoga dispositivos das Leis $n^{\circ}$ 9.424, de 24 de dezembro de 1996, 10.880, de 9 de junho de 2004, e 10.845, de 5 de março de 2004, e dá outras providências (Lei do FUNDEB). Diário Oficial da União, Brasília, DF, 22 jun. 2007. Disponível em: <http:// www.planalto.gov.br/ccivil_03/_ato2007-2010/2007/Lei/L11494.htm>. Acesso em: 22 ago. 2009.

BRASIL. Lei no 11.738, de 16 de julho de 2008. Regulamenta a alínea "e" do inciso III do caput do art. 60 do Ato das Disposições Constitucionais Transitórias, para instituir o piso salarial profissional nacional para os profissionais do magistério público da educação básica (Lei do PSPN). Diário Oficial da União, Brasília, DF, 17 jul. 2008. Disponível em: < http://www.planalto.gov.br/ccivil_03/_ato20072010/2008/lei/l11738.htm>. Acesso em: 22 ago. 2009.

CAMPINA GRANDE DO SUL. Lei Municipal Ordinária n² 22 de 2003. Autoriza o reajuste da tabela de vencimentos do Quadro Próprio do Magistério, constante do anexo II da Lei $n^{\circ} 17 / 98$ de 30 de junho de 1998 e dá outras providências. Disponível em: <http://www.pmcgs. pr.gov.br/portal/>. Acesso em: 13 jun. 2011. 
CAMPINA GRANDE DO SUL. Lei Municipal Ordinária nº 2 de 2008. Altera a Lei $n^{\circ} 17$, de 30 de junho de 1998, que dispõe a respeito do Plano de Carreira e Remuneração do Magistério Municipal de Campina Grande do Sul, e dá outras providências. Disponível em: < http://www. pmcgs.pr.gov.br/portal/>. Acesso em: 13 jun. 2011.

CAMPINA GRANDE DO SUL. Lei Municipal Ordinária nº 26 de 2010. Autoriza reajuste salarial dos servidores municipais e dá outras providências. Disponível em: <http://www.pmcgs.pr.gov.br/portal/> . Acesso em: 13 jun. 2011.

CAMPO LARGO. Lei Municipal Ordinária nº 1.682 de 2003. Autoriza o reajuste de vencimentos para os integrantes do Quadro de Servidores do Poder Executivo e do Plano de Carreira do Magistério Municipal, conforme especifica. 2003. Disponível em: < http://www.leismunicipais. com.br >. Acesso em: 20 jun. 2011.

CAMPO LARGO. Lei Municipal Ordinária nº 1.936 de 2007. Dá nova redação ao artigo 40 da lei municipal n 1647/02 e suas alterações, conforme especifica. 2007. Disponível em: < http://www.leismunicipais. com.br>. Acesso em: 20 jun. 2011.

CAMPO LARGO. Lei Municipal Ordinária nº 2.119 de 2009. Concede reajuste salarial aos servidores públicos municipais e dá outras providências, conforme especifica. 2009. Disponível em: < http://www. leismunicipais.com.br >. Acesso em: 20 jun. 2011.

CAMPO MAGRO. Lei Municipal Ordinária n 222 de 2002. Altera o valor constante do art. 32, e por consequência, a tabela de Vencimentos dos Profissionais do Magistério, constante do Anexo I da Lei nº 78/2001. 2002.

CAMPO MAGRO. Lei Municipal Ordinária nº 416 de 2006. Dá nova redação ao artigo 32, da Lei $n^{\circ}$ 78/2001, que dispõe sobre o Plano de Carreira do Magistério Público do Município de Campo Magro, alterado pela Lei Municipal de n³ 348/2005. 2006.

CAMPO MAGRO. Lei Municipal Ordinária nº 540 de 2009. Dispõe sobre o Estatuto e o Plano de Cargos e Salários do Profissional da Educação do Município de Campo Magro e revoga as Leis n¹78/2001, 438/2005, 351/2005, 416/2006 e 478/2007. Diário Oficial do Município, Campo Magro, PR, 3 set. 2009.

COLOMBO. Tabela de vencimentos. APMC Sindicato, 2007.

COLOMBO. Tabela de vencimentos. APMC Sindicato, 2010.

CURITIBA. Tabela de vencimentos. APP Sindicato, 2003. 
CURITIBA. Tabela de vencimentos. APP Sindicato, 2007.

CURITIBA. Tabela de vencimentos. APP Sindicato, 2010.

FAZENDA RIO GRANDE. Secretaria Municipal de Administração. Tabela de salário base professor. 2003.

FAZENDA RIO GRANDE. Secretaria Municipal de Administração. Tabela de salário base professor. 2007.

FAZENDA RIO GRANDE. Secretaria Municipal de Administração. Tabela de salário base professor. 2010.

PINHAIS. Lei Municipal Ordinária n 510 de 2002. Concede reposição salarial aos servidores municipais e dá outras providências. 2002. Disponível em: <http://www.leismunicipais.com.br>. Acesso em: 30 abr. 2011.

PINHAIS. Lei Municipal Ordinária n 771 de 2007. Concede reposição salarial aos servidores municipais e dá outras providências. 2007.

Disponível em: <http://www.leismunicipais.com.br>. Acesso em: 30 abr. 2011.

PINHAIS. Lei Municipal Ordinária n 950 de 2009. Concede revisão geral anual de salário dos servidores municipais. 2009. Disponível em: <http://www.leismunicipais.com.br>. Acesso em: 30 abr. 2011.

PIRAQUARA. Lei Municipal Ordinária nº 726 de 2004. Institui o Plano de Cargos, Emprego, Carreira, Vencimentos e Salários do Magistério Público Municipal. 2004. Disponível em: < http://www.leismunicipais. com.br>. Acesso em: 08 maio 2011.

PIRAQUARA. Lei Municipal Ordinária nº 878 de 2006. Autoriza o chefe do poder executivo municipal a conceder reajuste salarial aos professores da rede municipal e dá outras providências. 2006. Disponível em: <http://www.leismunicipais.com.br>. Acesso em: 08 maio 2011.

PIRAQUARA. Lei Municipal Ordinária nº 947 de 2008. Dá nova redação à lei n 726/2004, de 24/06/2004 e dá outras providências. 2008. Disponível em: <http://www.leismunicipais.com.br>. Acesso em: 8 maio 2011.

QUATRO BARRAS. Prefeitura municipal. Vencimento mensal do grupo ocupacional magistério. 2003.

QUATRO BARRAS. Prefeitura municipal. Vencimento mensal do grupo ocupacional magistério. 2007. 
QUATRO BARRAS. Prefeitura municipal. Vencimento mensal do grupo ocupacional magistério. 2010.

SÃO JOSÉ DOS PINHAIS. Lei Complementar nº 2 de 2004. Dispõe sobre o Plano de Cargos, Carreiras e Vencimentos dos Servidores do Poder Executivo Municipal. 2004. Disponível em:<http://www. leismunicipais.com.br >. Acesso em: 6 jul. 2011.

SÃO JOSÉ DOS PINHAIS. Sindicato dos Servidores Públicos Municipais (Sinsep). Tabela de níveis cargos efetivos. 2010.

Juliana Aparecida Alves Subirá, mestre em Educação na linha de Políticas e Gestão da Educação pela Universidade Federal do Paraná (UFPR), é membro do grupo de pesquisa sobre remuneração dos professores junto ao Núcleo de Pesquisa em Políticas, Gestão e Financiamento da Educação na Universidade Federal do Paraná e Observatório da Educação, Curitiba, Paraná, Brasil.

jsubira@ig.com.br

Recebido em 31 de agosto de 2010.

Aprovado em $1^{\circ}$ de março de 2013. 